\title{
Interim Measure Conceptual Design for Remediation of Source Area Contamination at Agra, Kansas
}

\author{
Environmental Science Division
}




\begin{abstract}
About Argonne National Laboratory
Argonne is a U.S. Department of Energy laboratory managed by UChicago Argonne, LLC under contract DE-AC02-06CH11357. The Laboratory's main facility is outside Chicago, at 9700 South Cass Avenue, Argonne, Illinois 60439. For information about Argonne, see www.anl.gov.
\end{abstract}

\title{
Availability of This Report
}

This report is available, at no cost, at http://www.osti.gov/bridge. It is also available on paper to the U.S. Department of Energy and its contractors, for a processing fee, from:

U.S. Department of Energy

Office of Scientific and Technical Information

P.O. Box 62

Oak Ridge, TN 37831-0062

phone (865) 576-8401

fax (865) 576-5728

reports@adonis.osti.gov

\section{Disclaimer}

This report was prepared as an account of work sponsored by an agency of the United States Government. Reference herein to any specific commercial product, process, or service by trade name, trademark, manufacturer, or otherwise, does not necessarily constitute or imply its endorsement, recommendation, or favoring by the United States Government or any agency thereof. The views and opinions of document authors expressed herein do not necessarily state or reflect those of the United States Government or any agency thereof, Argonne National Laboratory, or UChicago Argonne, LLC. 


\section{Interim Measure Conceptual Design for Remediation of Source Area Contamination at Agra, Kansas}

by

Applied Geosciences and Environmental Management Section Environmental Science Division, Argonne National Laboratory

July 2007 


\section{Contents}



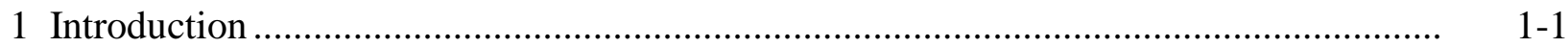

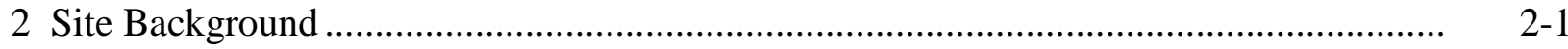

3 Previous Investigations and Summary of Results ................................................

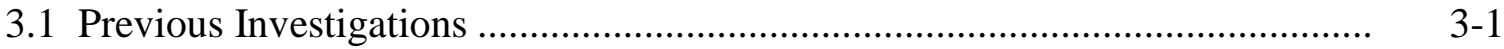

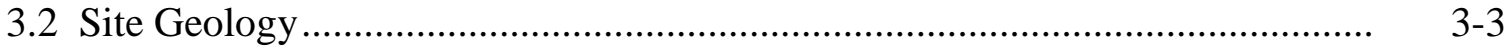

4 Proposed Source Control and Mass Removal Interim Measure .................................. 4-1

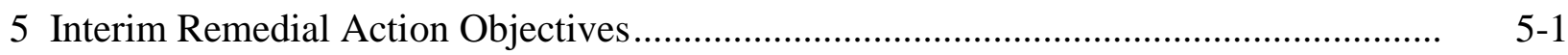

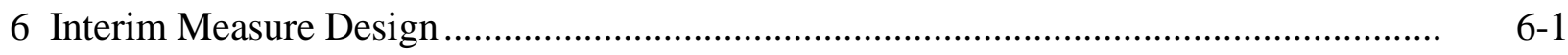

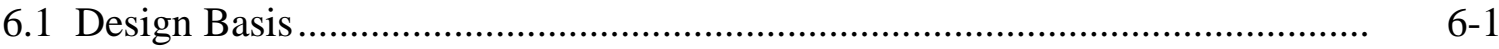

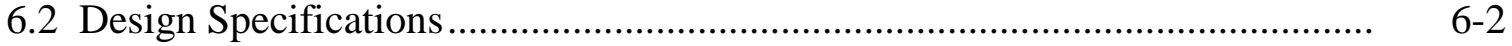

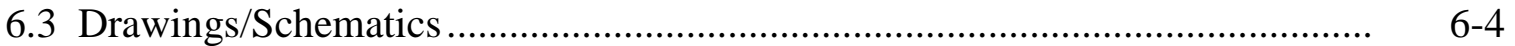

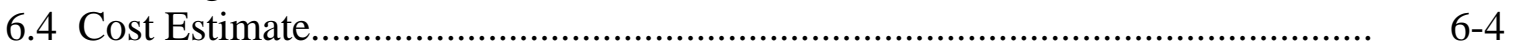

6.5 Detailed Working Schedule .................................................................... $\quad 6-4$

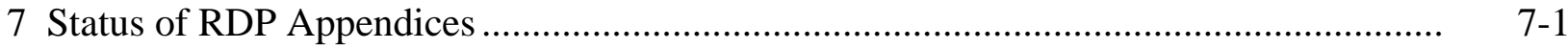

7.1 RDP Appendix A: Data Acquisition Plan ......................................................

7.2 RDP Appendix B: Quality Assurance Project Plan ...................................... 7 7

7.3 RDP Appendix C: Treatability Study Testing Plan ...................................... 7-1

7.4 RDP Appendix D: Health and Safety Plan......................................................

7.5 RDP Appendix E: Operations and Maintenance Plan..................................... 7-1

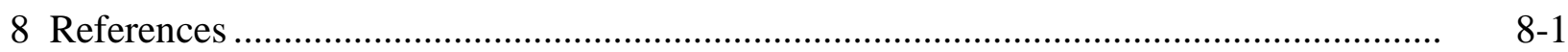

Appendix A: Summary of Analytical Results for Soil and Groundwater Samples Collected at Agra in 2005.................................................................... A- A

\section{Tables}

3.1 History of investigations of carbon tetrachloride contamination at Agra, Kansas... 3-5

6.1 Kansas sites where LDB technology has been deployed ................................... $6-2$ 


\section{Tables (Cont.)}

6.2 Working schedule for remediation system installation.....

A.1 Summary of analytical results for soil samples collected on the former CCC/USDA property during the 2005 investigation at Agra, Kansas....

A.2 Summary of analytical results for soil samples collected on and near the Pro-Ag Co-op property during the 2005 investigation at Agra, Kansas

A.3 Summary of analytical results for soil samples collected at and near the former retail store during the 2005 investigation at Agra, Kansas

A.4 Summary of results of organic analyses on groundwater samples collected on the former CCC/USDA property during the 2005 investigation at Agra, Kansas

A.5 Summary of results of organic analyses on groundwater samples collected on and near the Pro-Ag Co-op property during the 2005 investigation at Agra, Kansas

A.6 Summary of results of organic analyses on groundwater samples collected at or near the former retail store during the 2005 investigation at Agra, Kansas ......

A.7 Summary of results of organic analyses on groundwater samples collected at downgradient CPT locations and permanent monitoring points outside the target investigation areas during the 2005 investigation at Agra, Kansas

\section{Figures}

2.1 Location of Agra, Kansas

2.2 Historical aerial photograph showing grain storage facilities

at Agra, Kansas

2.3 Distribution of carbon tetrachloride in groundwater at Agra, summer 2005.

2.4 Investigated locations in the three target areas of the 2005 study at Agra

3.1 Locations of hydrogeologic cross sections A-A', B-B', C-C', and D-D' at Agra ....... 


\section{Figures (Cont.)}

3.2 Horizontal and vertical distribution of carbon tetrachloride in soil and groundwater at Agra, shown on north-to-south hydrogeologic cross section B-B', across the Pro-Ag Co-op property, Railroad Avenue, and the former store property

3.3 Horizontal and vertical distribution of carbon tetrachloride in soil and groundwater at Agra, shown on west-to-east hydrogeologic cross section A-A', across the Pro-Ag Co-op property

3.4 Horizontal and vertical distribution of carbon tetrachloride in soil and groundwater at Agra, shown on west-to-east hydrogeologic cross section D-D', on the former CCC/USDA facility

3.5 Horizontal and vertical distribution of carbon tetrachloride in soil and groundwater at Agra, shown on north-to-south hydrogeologic cross section C-C' across the former CCC/USDA facility and the Pro-Ag Co-op property

6.1 Initial screening for the effectiveness of LDB technology

6.2 Tentative locations proposed for LDB technology installations and control points

6.3 Proposed well design for an LDB installation with AS-SVE system at Agra 


\section{Notation}

$\begin{array}{ll}\text { AS } & \text { air sparging } \\ \text { BGL } & \text { below ground level } \\ \text { CAS } & \text { Corrective Action Study } \\ \text { CCC } & \text { Commodity Credit Corporation } \\ \text { CPT } & \text { cone penetrometer } \\ \text { 1,2-DCA } & \text { 1,2-dichloroethane } \\ \text { EPA } & \text { U.S. Environmental Protection Agency } \\ \text { ESC } & \text { Expedited Site Characterization } \\ \text { ft } & \text { foot (feet) } \\ \text { IM } & \text { interim measure } \\ \text { in. } & \text { inch(es) } \\ \text { KDHE } & \text { Kansas Department of Health and Environment } \\ \text { LDB } & \text { large-diameter borehole } \\ \mu \text { /kg } & \text { microgram(s) per kilogram } \\ \mu \text { /L } & \text { microgram(s) per liter } \\ \text { MCL } & \text { maximum contaminant level } \\ \text { mi } & \text { mile(s) } \\ \text { NEC } & \text { National Electrical Code } \\ \text { NFPA } & \text { National Fire Protection Association } \\ \text { O\&M } & \text { operations and maintenance } \\ \text { PWS } & \text { public water supply } \\ \text { RBSL } & \text { Risk-Based Screening Level } \\ \text { RDP } & \text { remedial design plan } \\ \text { SVE } & \text { soil vapor extraction } \\ \text { USDA } & \text { U.S. Department of Agriculture } \\ & \end{array}$




\section{Interim Measure Conceptual Design for Remediation of Source Area Contamination at Agra, Kansas}

\section{Introduction}

This document presents a conceptual design for the implementation of a non-emergency interim measure (IM) at the site of the grain storage facility formerly operated by the Commodity Credit Corporation of the U.S. Department of Agriculture (CCC/USDA) in Agra, Kansas. The IM is recommended to mitigate localized carbon tetrachloride contamination in the vadose zone soils at the former CCC/USDA facility and eliminate ongoing soil-to-groundwater contamination.

The objectives of this IM conceptual design report include the following:

1. Obtain written acknowledgement from the Kansas Department of Health and the Environment (KDHE) that remediation on the former CCC/USDA property is required.

2. Provide information (IM description, justification for the IM, and project schedule) that the KDHE can include in a pending fact sheet.

3. Obtain KDHE approval for the IM conceptual design, so that the CCC/USDA can initiate a formal request for access to the privately owned property and proceed with preparation of a remedial design plan (RDP).

Investigations conducted on behalf of the CCC/USDA by Argonne National Laboratory (Argonne 2006) have demonstrated that soil and groundwater at the Agra site are contaminated with carbon tetrachloride. The levels in groundwater exceed the Kansas Tier 2 Risk-Based Screening Level (RBSL) and the U.S. Environmental Protection Agency (EPA) maximum contaminant level (MCL) of $5.0 \mu \mathrm{g} / \mathrm{L}$ for this compound. The soil and groundwater contamination identified at the former CCC/USDA facility currently poses no unacceptable health risks.

This report was developed in accordance with KDHE Bureau of Environmental Remediation Policy \#BER-RS-029 (KDHE 1996), supplemented by guidance from the KDHE 
project manager. If the IM conceptual design is accepted by the KDHE, the CCC/USDA (in consultation with a remediation contractor) will prepare an RDP. The RDP will contain the following elements:

- Detailed description of the IM

- Justification for and benefits of the IM (including IM action objectives)

- Complete design specifications

- Drawings and/or schematics

- Relevant figures and/or site system engineering layouts

- Engineering design basis

- Detailed working schedule

- Detailed operations and maintenance (O\&M) plan

- Proposed performance monitoring plan 


\section{Site Background}

The city of Agra, Kansas, is located in Phillips County, in the northwestern corner of the state (Figure 2.1). The town lies about $275 \mathrm{mi}$ northwest of Topeka, Kansas. The current population of Agra is approximately 283 (U.S. Census Bureau, 2004 estimate).

The CCC/USDA operated a grain storage facility approximately $175 \mathrm{ft}$ north of the city limits of Agra from the 1950s to the early 1970s (Figure 2.2). No structures remain on the property, and the land is currently used for agriculture purposes, specifically wheat production. The property is currently owned by Mid States Port Authority and is leased to Mr. Herb VanEaton.

In 1985, carbon tetrachloride was detected in groundwater samples collected by the KDHE from Agra public water supply wells PWS-3 and PWS-4. These wells are located approximately $500 \mathrm{ft}$ south of investigation location SB80 (Figure 2.3). The concentrations detected in $1985(3.0 \mu \mathrm{g} / \mathrm{L}$ and $1.2 \mu \mathrm{g} / \mathrm{L}$, respectively) were below the RBSL and MCL of $5.0 \mu \mathrm{g} / \mathrm{L}$ for carbon tetrachloride in drinking water supplies. Subsequently, the KDHE required city officials to test groundwater from these wells annually. During a 1986 sampling event, carbon tetrachloride was detected at $12 \mu \mathrm{g} / \mathrm{L}$ in PWS-3. In response to the elevated concentration, the KDHE required the city to remove both PWS-3 and PWS-4 from service (KDHE 1986).

In 2005 the Environmental Science Division of Argonne National Laboratory implemented a comprehensive investigation of potential contaminant source areas at Agra, on behalf of the CCC/USDA. The investigated locations are illustrated in Figure 2.4. The investigation was conducted at the request of the KDHE (Gotto 2004).

Data collected during the 2005 investigation identified three primary source areas for carbon tetrachloride contamination (Figure 2.3). One source is located on the former CCC/USDA property, and the other two sources are on property currently owned by the Pro-Ag Cooperative. To address the contamination detected on its former property, the CCC/USDA proposes to implement a source area IM. The IM will consist of large-diameter boreholes (LDBs) coupled with soil vapor extraction (SVE) and air sparging (AS). 


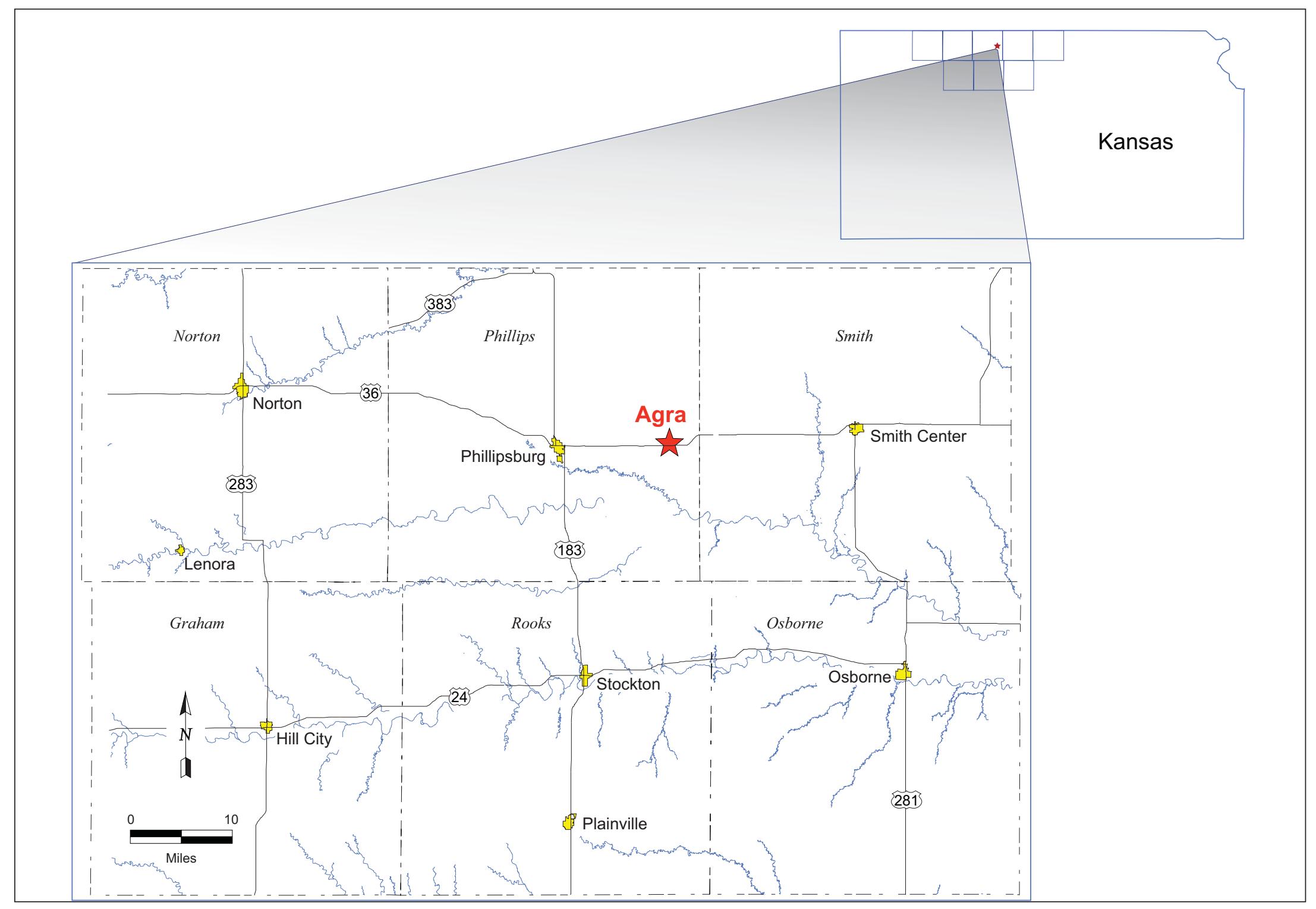




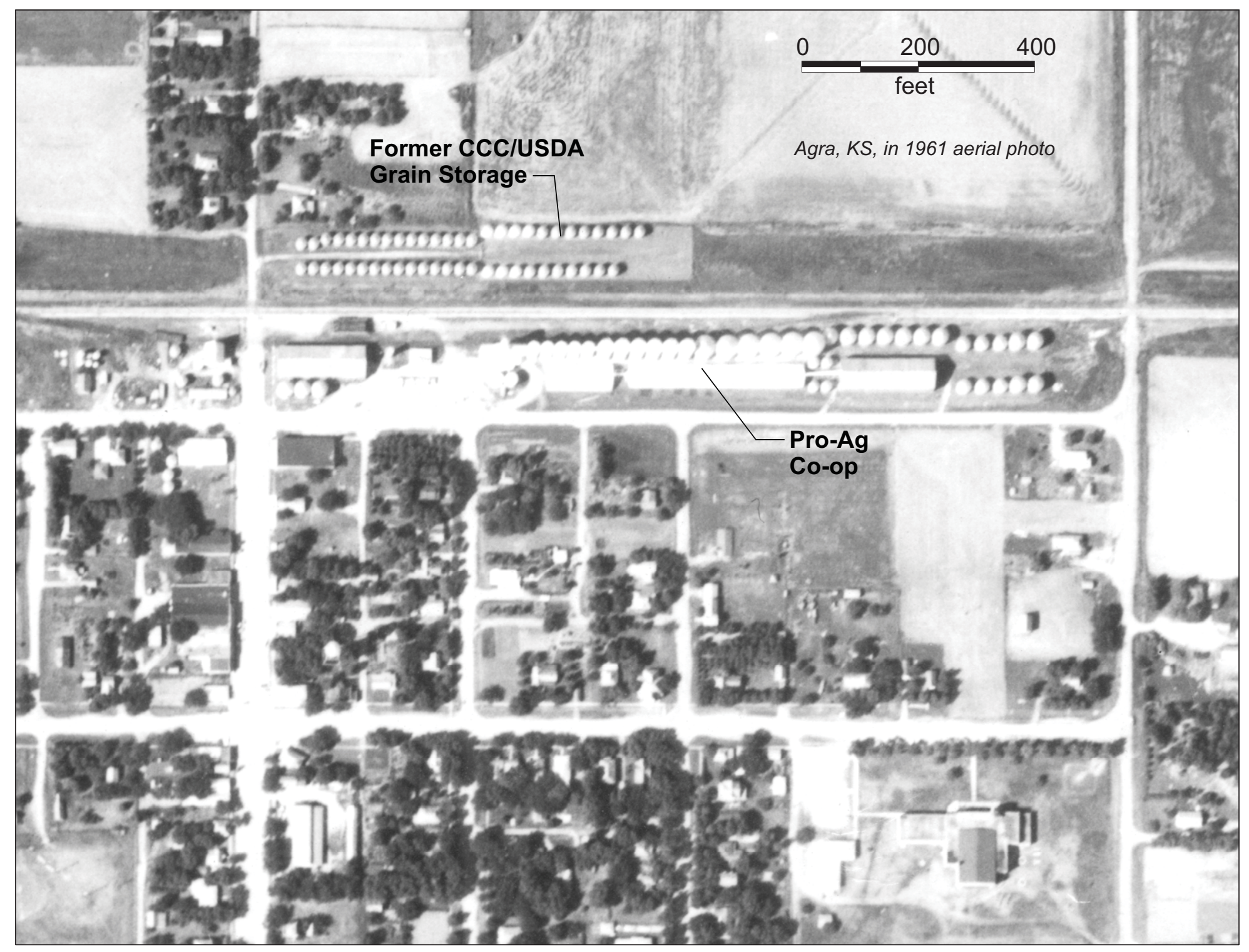

FIGURE 2.2 Historical aerial photograph showing grain storage facilities at Agra, Kansas. Source of photograph: USDA (1961). 


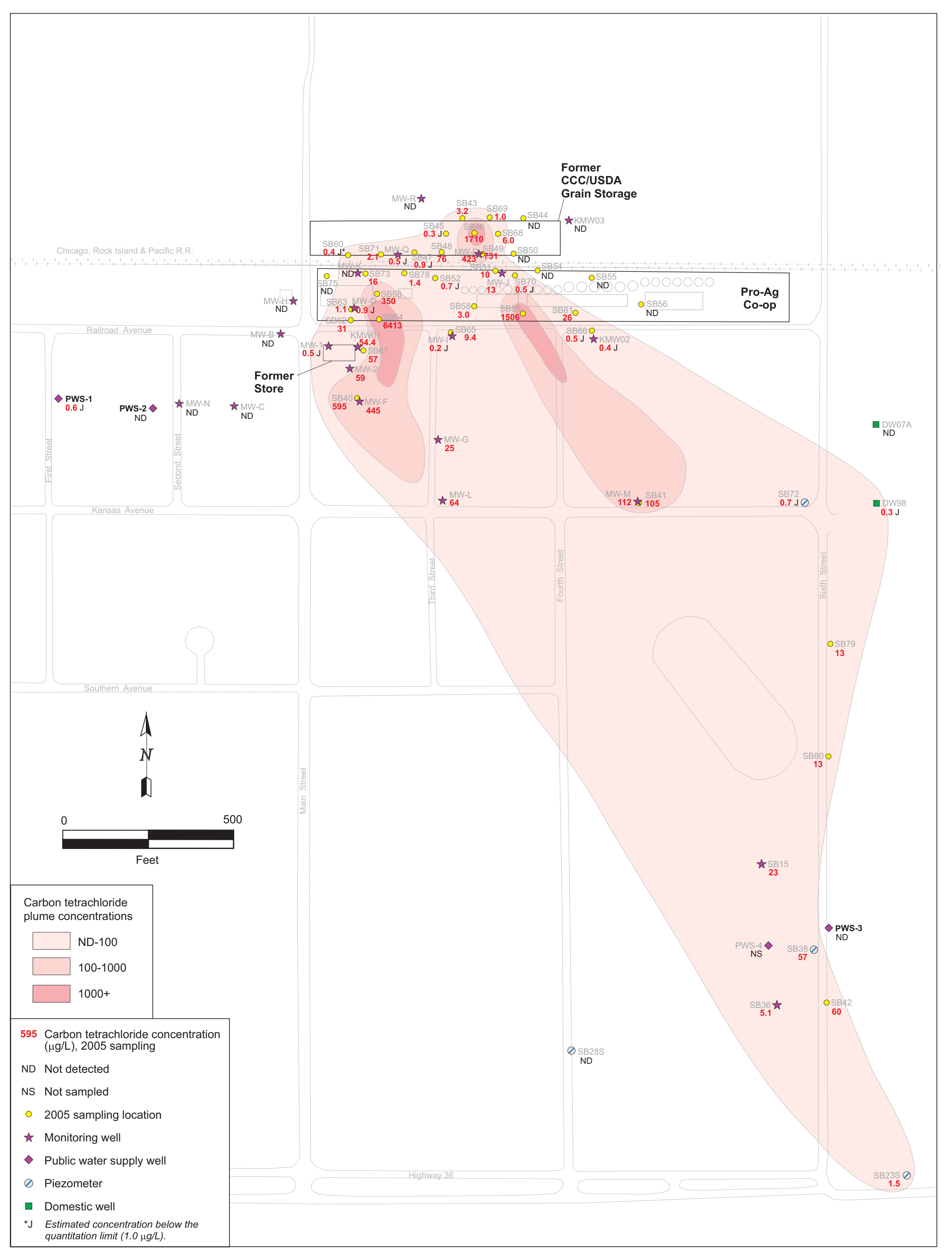

FIGURE 2.3 Distribution of carbon tetrachloride in groundwater at Agra, summer 2005. 


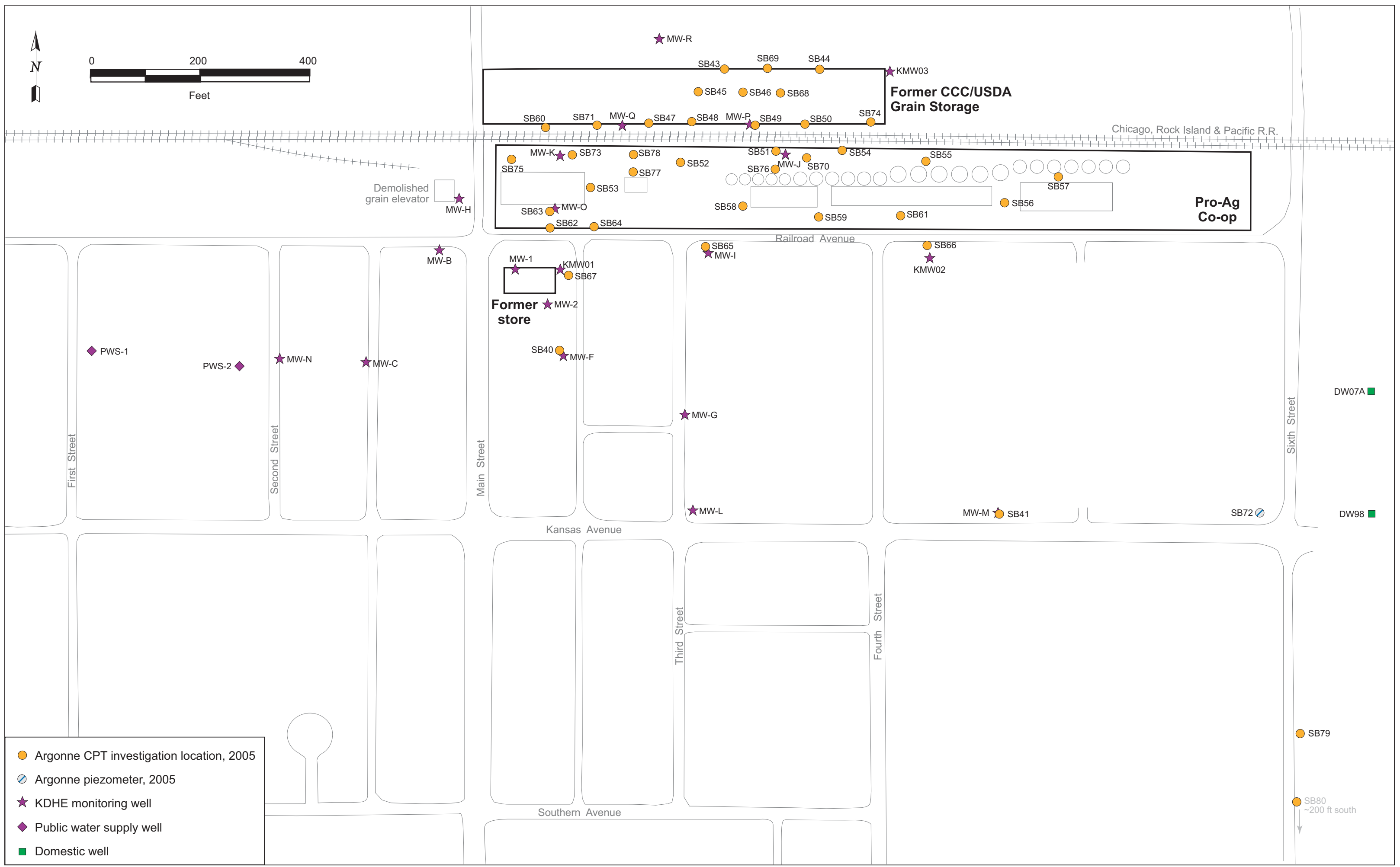

FIGURE 2.4 Investigated locations in the three target areas of the 2005 study at Agra 


\section{Previous Investigations and Summary of Results}

\subsection{Previous Investigations}

From 1986 to 1998, several investigations were conducted at the Agra site. The history of investigations and monitoring in 1985-1999 is summarized in Table 3.1.

In 2005, Argonne conducted a comprehensive investigation of source areas on the former CCC/USDA Agra property, the Pro-Ag property, and a former retail store. One source area was identified near the center of the former CCC/USDA property. Two sources areas were identified on the Pro-Ag property: one near the west side of the property and the other near the center (Figure 2.3). All data collected during the 2005 investigation were discussed thoroughly in a report submitted to and approved by the KDHE (Argonne 2006).

During the 2005 investigation, carbon tetrachloride was detected above the RBSL of $200 \mu \mathrm{g} / \mathrm{kg}$ for the soil-to-groundwater protection pathway in 7 of the 79 soil samples collected with the cone penetrometer (CPT) (at 2 of the 6 locations sampled) on the former CCC/USDA Agra property (Table A.1 in Appendix A). The highest carbon tetrachloride levels in soil samples occurred near the east-central part of the property at SB46 $(2,273 \mu \mathrm{g} / \mathrm{kg}$ at $44 \mathrm{ft}$ below ground level [BGL], just above the saturated zone).

Carbon tetrachloride was detected in groundwater at or above the MCL of $5.0 \mu \mathrm{g} / \mathrm{L}$ in 13 of the 58 samples collected from monitoring wells or CPT boreholes (at 4 of 15 locations sampled) on the former CCC/USDA Agra property (Table A.4 in Appendix A). The highest concentration (1,710 $\mu \mathrm{g} / \mathrm{L}$ at $45-50 \mathrm{ft} \mathrm{BGL}$ ) was again detected at SB46 (Figure 2.3).

The source areas identified on the Pro-Ag property include two general areas where supporting data were collected from three CPT boreholes. These are CPT locations SB53, SB59, and SB64 (Figure 2.3).

Carbon tetrachloride was detected above the RBSL of $200 \mu \mathrm{g} / \mathrm{kg}$ for the soil-togroundwater protection pathway in 5 of the 159 soil samples collected with the CPT (at 2 of the 13 locations sampled) on the Pro-Ag Co-op property (Table A.2 in Appendix A). The maximum 
concentrations were $52 \mu \mathrm{g} / \mathrm{kg}$ at SB53 (40 ft BGL), $728 \mu \mathrm{g} / \mathrm{kg}$ at SB59 (48 ft BGL), and $1,604 \mu \mathrm{g} / \mathrm{kg}$ at SB64 (within the saturated zone at $48 \mathrm{ft} \mathrm{BGL}$ ).

Carbon tetrachloride was detected in groundwater at or above the MCL of $5.0 \mu \mathrm{g} / \mathrm{L}$ in 28 of the 87 groundwater samples collected from monitoring wells and CPT boreholes (at 9 of 24 locations sampled) on the Pro-Ag Co-op property (Table A.5 in Appendix A). The highest concentrations occurred in the source areas (Figure 2.3): $350 \mu \mathrm{g} / \mathrm{L}$ at SB53 (58-63 ft BGL); 1,506 $\mu \mathrm{g} / \mathrm{L}$ at SB59 (45-50 ft BGL); and 6,413 $\mu \mathrm{g} / \mathrm{L}$ at SB64 (48-53 ft BGL).

1,2-Dichloroethane (1,2-DCA) was found in both soil and groundwater samples collected at SB53 and in groundwater samples collected at SB59 and SB64 (Tables A.2 and A.5 in Appendix A).

Also investigated during the 2005 investigation was the former retail store immediately south of the Pro-Ag property (Tables A.3 and A.6 in Appendix A). The data collected did not rule out a source area at the former retail store. However, identification of a separation between contaminant plumes emanating from the Pro-Ag Co-op property and the former retail store property was beyond the scope of this investigation.

Carbon tetrachloride was detected at or above the method quantitation limit of $10 \mu \mathrm{g} / \mathrm{kg}$ (but below the RBSL) in 1 of the 12 soil samples collected at location SB67 on the former retail store property ( $47 \mu \mathrm{g} / \mathrm{kg}$ at $48 \mathrm{ft}$ BGL). Carbon tetrachloride was detected in groundwater at or above the MCL of $5.0 \mu \mathrm{g} / \mathrm{L}$ in all of the 3 groundwater samples collected at SB67, as well as in samples from 2 of the 3 monitoring wells on or near the former retail store property. The concentrations in the 5 samples were similar $(22-59 \mu \mathrm{g} / \mathrm{L}$ at depths between $40 \mathrm{ft}$ and $61.5 \mathrm{ft}$ BGL in SB67, KMW01, and MW-1) (Figure 2.3). No 1,2-DCA was detected in soil or groundwater samples collected at or near the former retail store.

Other data collected during the 2005 investigation included numerous groundwater samples from area monitoring wells (Table A.7 in Appendix A). The data indicate that the carbon tetrachloride contaminant plume is generally widespread. Points of origin for the contamination were found in the targeted source areas in the north-central to northeastern section of Agra. Contaminant migration was determined to be predominantly toward the southeast. Also detected in groundwater samples were elevated levels of nitrate, with maximum detected values near SB59 and SB64 on the Pro-Ag Co-op property (Figure 3.10 in Argonne 2006). 


\subsection{Site Geology}

Remedial options and contaminant migration pathways were investigated and considered through an analysis of the lateral and vertical distribution of carbon tetrachloride in soil and groundwater on the former CCC/USDA Agra property. Additional factors considered in identifying the most appropriate approach to the mitigation of the contamination at the Agra investigation site were (1) results of a detailed study of soil types (based on grain size analyses on selected samples), (2) an evaluation of the CPT electronic data recovered during the investigation, and (3) potentially suitable remedial technologies. The soil samples and the electronic sensor data were collected and evaluated by Kansas-licensed geologists, and grain size analyses were conducted by a laboratory certified for geotechnical testing. The lithologic logs and electronic sensor data were presented previously (Appendix A in Argonne 2006), as were the grain size analysis results (Table S1.2, Supplement 1 [on compact disc] in Argonne 2006). The lithologic data were further compiled and interpreted for this IM conceptual design document. Locations of the resulting cross sections are depicted in Figure 3.1.

The lithology identified along the western portion of the Pro-Ag Co-op property (B-B'; Figure 3.2) consists of silty clay to clayey silt interbedded with silt, clayey silt with sand, and silty sand to sandy silt. A continuous layer of clayey silt with sand and sandy silt to silty sand was observed in all boreholes along this section. The layer of clayey silt with sand ranged from $0.75 \mathrm{ft}$ thick at $12 \mathrm{ft}$ BGL in the northern part of the section (SB73) to about $13 \mathrm{ft}$ at SB67. This lithology was also observed at greater depths in all boreholes, ranging from about $1 \mathrm{ft}$ thick at SB73 to at least $23 \mathrm{ft}$ thick at SB64. A thin layer of silty sand to sandy silt was observed at about $23.5 \mathrm{ft}$ BGL at SB73. The thickness of this layer increases to $8 \mathrm{ft}$ in SB53 and then gradually thins toward SB67. Bedrock along this cross section was encountered at depths of about $59 \mathrm{ft}$ to $68 \mathrm{ft}$ BGL.

The cross section from west to east on the Pro-Ag Co-op property is represented by A-A' (Figure 3.3). The most continuous layers identified along this section were silty clay and clayey silt in the upper zone, underlain by silty sandy clay to clayey sandy silt. The silty clay to clayey silt layer extended across the entire area, and the silty sandy clay to clayey sandy silt was observed in all boreholes except SB63. These predominant zones were interbedded with discontinuous layers of silty sand and sandy silt, silt, and clayey silt with gravel. Bedrock depth varies significantly across the Pro-Ag Co-op property. At the western part of the property bedrock was encountered at $60 \mathrm{ft}$ BGL (SB63); its depth increased toward the east to $118 \mathrm{ft} \mathrm{BGL}$ 
(SB56). A core sample of bedrock material was collected at SB63. Bedrock consisted of dark gray, highly weathered shale.

The lithology identified across the former CCC/USDA Agra property (D-D'; Figure 3.4) consists of a zone of clayey silt or silty clay 20-26 ft thick, underlain by a discontinuous layer of silty sandy clay to clayey sandy silt. Within this layer are a few minor lenses of sand, silt, and clay, as well as thicker zones of clayey silt to silty clay. Bedrock at the former CCC/USDA Agra property was encountered at depths of about $64-68 \mathrm{ft}$ BGL in all but one borehole. The exception is CPT borehole SB44, located along the northern property boundary (not shown in the cross sections), where bedrock was encountered at $56 \mathrm{ft}$ BGL.

The only borehole that contained substantial gravel units was SB51, as depicted in cross sections A-A' (Figure 3.3) and C-C' (Figure 3.5), in two layers at depths of 20-27.25 ft BGL and 42.9-46 ft BGL. These two layers were composed of clayey silt to silty clay with gravel and some sand. Significant amounts of gravel were not observed in any other borehole along cross section C-C' (Figure 3.5), though the silt in many of the core samples appeared to be coarse to very coarse.

Groundwater depths in monitoring wells at the targeted source areas indicated that static water levels ranged from approximately $44 \mathrm{ft}$ to $49 \mathrm{ft}$ BGL. Lithologic data support a single, unconfined aquifer system that is underlain by highly weathered shale. Saturated thickness ranges from about $15 \mathrm{ft}$ along the western part of the Pro-Ag Co-op property and the former CCC/USDA property to more than $70 \mathrm{ft}$ east of this area. Groundwater in the upper part of the aquifer was slow in production and limited in quantity. The lower part of the aquifer produced water, but the quantities were limited as well. Well PWS-1 is screened at 82-91 ft BGL, while well PWS-2 is screened at 73-82 ft BGL. 
TABLE 3.1 History of investigations of carbon tetrachloride contamination at Agra, Kansas (1985-1999).

Date

Description of Event

Sep 1985-

Aug 1986

Apr 1987

Oct $1987-$

Jun 1988

Aug 1991-

Oct 1991

Nov 1993

Mar 1995

Nov 1995 begin constructing additional wells. (Unified School District 234) septic system. private and public water supply wells. 1 mi east of town. four of the five wells sampled. properties.
Routine sampling of public supply wells PWS-3 and PWS-4 showed low

concentrations (below action levels) of carbon tetrachloride $(3.0 \mu \mathrm{g} / \mathrm{L}$ and $1.2 \mu \mathrm{g} / \mathrm{L}$, respectively). Resampling in August 1986 revealed carbon tetrachloride levels above the MCL of $5 \mu \mathrm{g} / \mathrm{L}(12 \mu \mathrm{g} / \mathrm{L}$ and $3 \mu \mathrm{g} / \mathrm{L}$, respectively). $\mathrm{KDHE}$ required the city to discontinue use of the wells, except if other city wells could not supply adequate quantities of water. The KDHE advised the city to

Preliminary Assessment. KDHE conducted a preliminary assessment of PWS-3 and PWS-4. Potential sources identified included the former CCC/USDA facility (originally misidentified as the Agra Co-op), the former Agra Co-op and Kensington Co-op property (now the location of the Pro-Ag Co-op), privately owned grain bins at the southwest corner of Main and Railroad, the former retail store at the southeast corner of Main and Railroad, and the public school

Site Inspection. The tasks completed during the site inspection included a soil gas survey of potential source areas, the installation of three monitoring wells, and sampling of private and public water supply wells. Analytical data indicated carbon tetrachloride in soil gas samples collected near the grain elevator and the former retail store. Groundwater samples indicated carbon tetrachloride in

City of Agra gave public water supply well PWS-4 to the high school to be used for irrigation of the football field, and the city installed a new supply well (PWS-5)

Site Assessment. The site assessment involved the collection of groundwater samples from two existing public water supply wells and three monitoring wells. The results showed concentrations of carbon tetrachloride above the MCL in

Comprehensive Investigation. The comprehensive investigation involved the collection and analysis of soil gas, surface soil, subsurface soil, and groundwater samples on the Pro-Ag Co-op property and in the vicinity of the former retail store. Carbon tetrachloride was detected in samples from both

Phase I Expedited Site Characterization (ESC). The Phase I ESC involved the collection and analysis of soil and groundwater samples; the installation of one monitoring well and one well point; and the characterization of local stratigraphy. No samples were collected on the Pro-Ag Co-op property.

Phase II ESC. The Phase II ESC involved the collection of surface soil, nearsurface soil, and groundwater samples; the installation of four monitoring wells; and a geophysical survey of the bedrock topography. The data indicated that the general extent of the contaminant plume had been delineated. Two distinct areas of contamination were identified, and the geophysical survey showed areas of significant relief in the bedrock topography.
Investigating Entity and Report Date

KDHE

Dec 1985,

Sep 1986

$\mathrm{KDHE}$

Apr 1987

$\mathrm{KDHE}$

Dec 1988

PRC

Environmental

for KDHE

Nov 1995

PRC

Environmental

for KDHE

Jul 1994

PRC

Environmental

for KDHE

Nov 1995

Argonne for

CCC/USDA

Nov 1995

Argonne for CCC/USDA

May 1996 
TABLE 3.1 (Cont.)

Date Description of Event

Investigating Entity

Jun 1996-

Sep 1996

May 1997-

Aug 1997

Sep 1998-

May 1999
Feasibility Study. The feasibility study was conducted to identify possible remedial alternatives. The work included the installation of one soil boring, one monitoring well, and three piezometers; an aquifer pump test; water level monitoring; fate and transport modeling of the contaminant plume; and examination of the health risks associated with exposure to contaminated groundwater.

Phase I Corrective Action Study (CAS). The CAS involved the collection of soil and groundwater samples and the installation of 18 monitoring wells in the vicinity of the former CCC/USDA property, the Pro-Ag Co-op property, and the former retail store, as well as at locations downgradient from these properties.

Monitoring. Groundwater samples were collected from existing monitoring wells in 1998 and 1999. The contaminant plume was identified as extending to the southeast from the vicinity of the source areas. The monitoring validated the identification of two distinct areas of contamination in Argonne's earlier study.
Argonne for CCC/USDA Jun 1997

BE\&K/Terranext for $\mathrm{KDHE}$ Jul 1998

BE\&K/Terranext for KDHE

Nov 1998

Jun 1999 


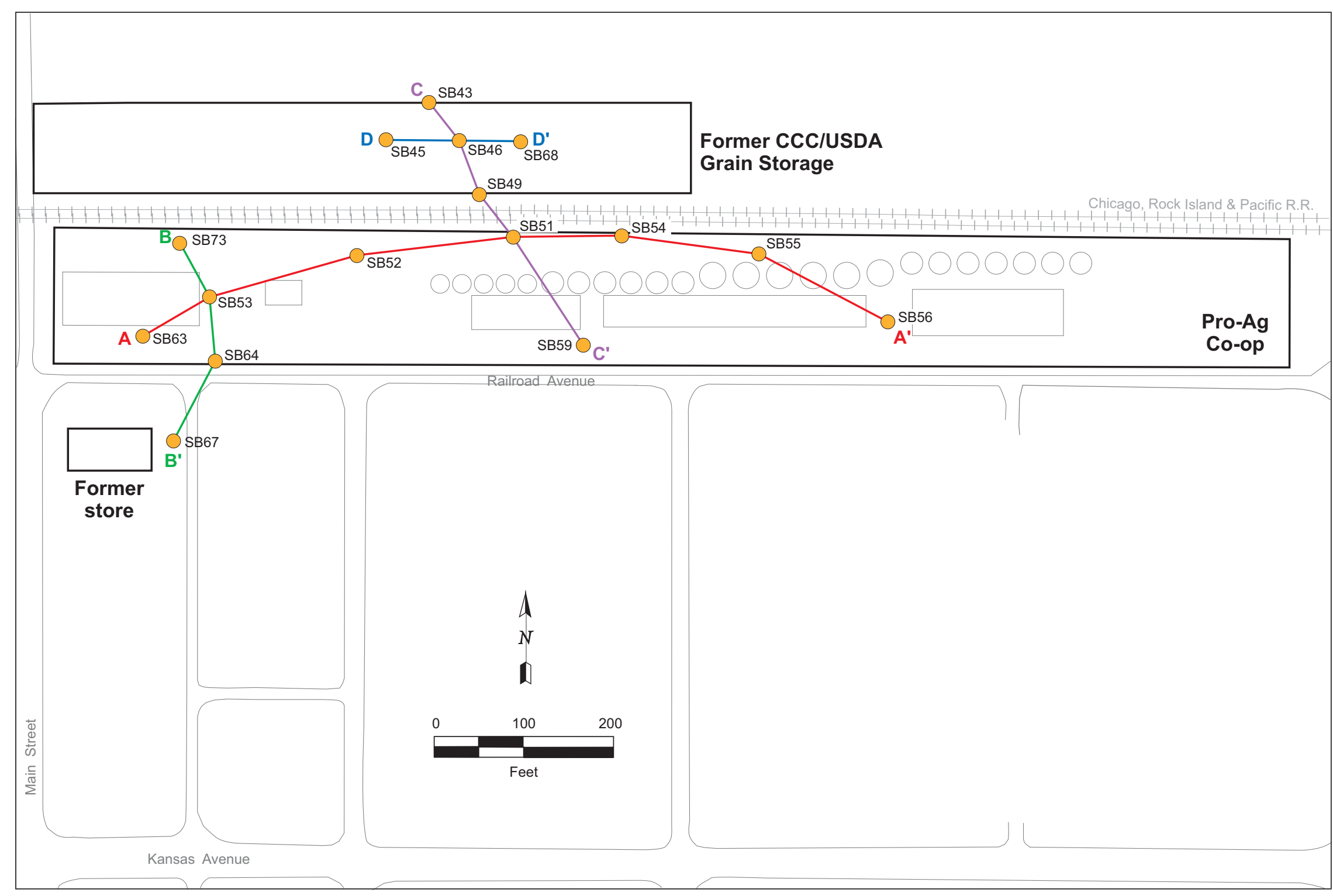

FIGURE 3.1 Locations of hydrogeologic cross sections A-A', B-B', C-C', and D-D' at Agra. 


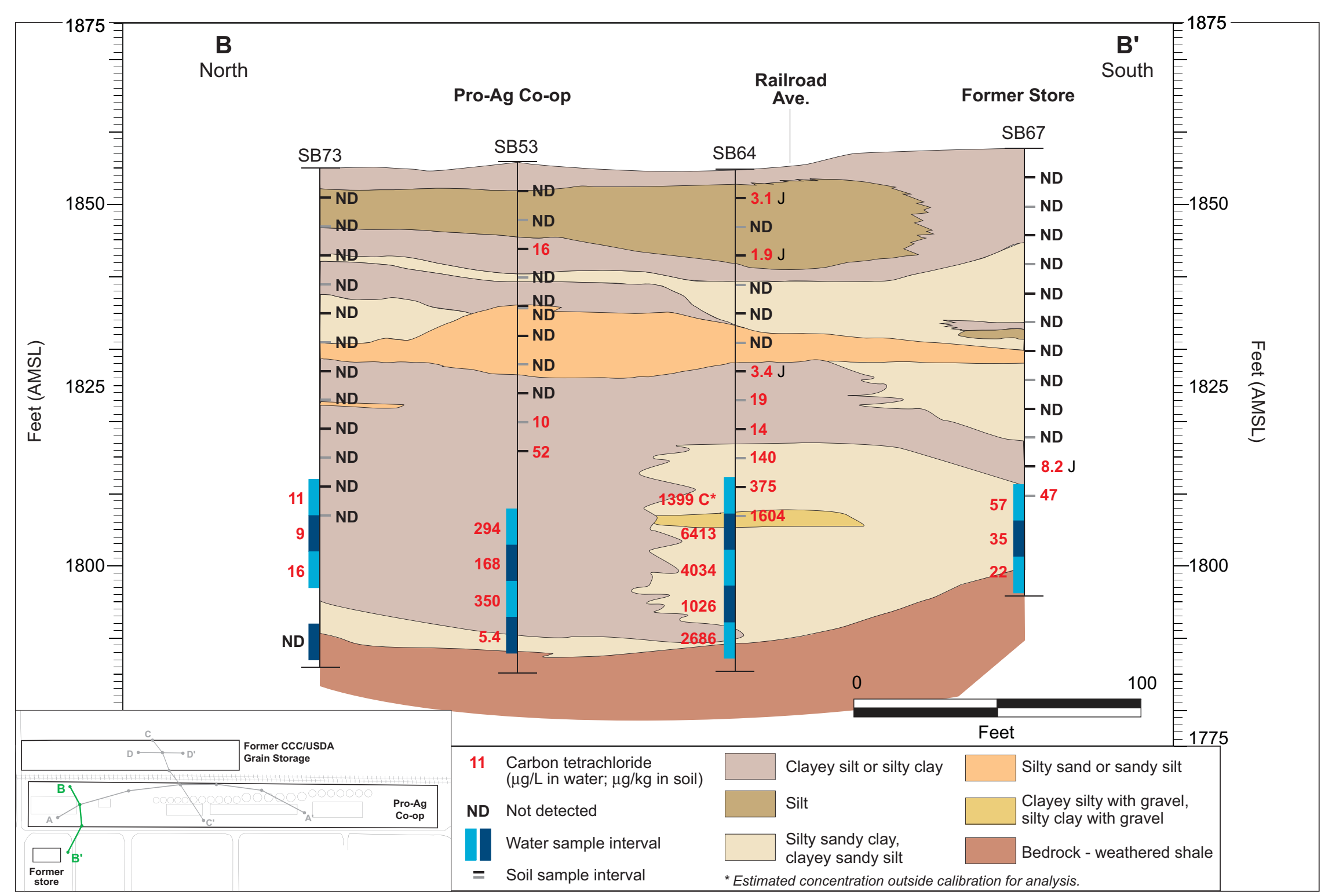

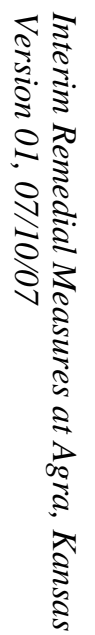

FIGURE 3.2 Horizontal and vertical distribution of carbon tetrachloride in soil and groundwater at Agra, shown on north-to-south hydrogeologic cross section B-B', across the Pro-Ag Co-op property, Railroad Avenue, and the former store property (vertically exaggerated). 


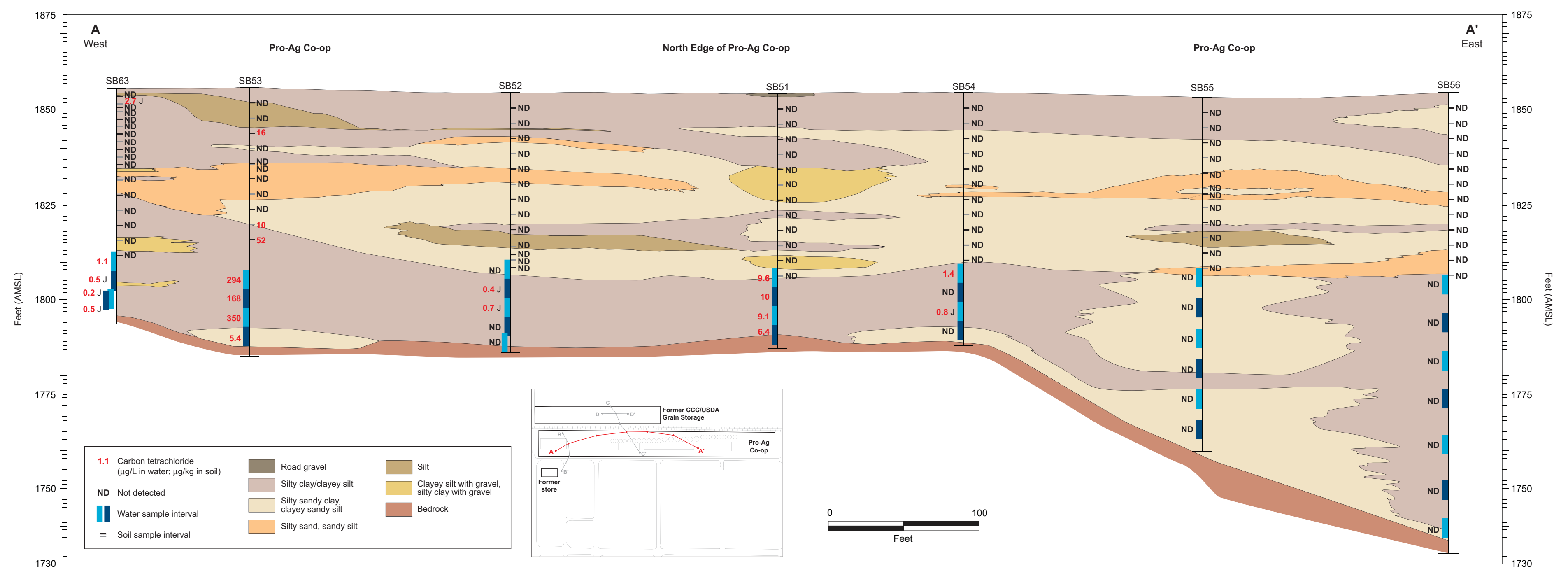

FIGURE 3.3 Horizontal and vertical distribution of carbon tetrachloride in soil and groundwater at Agra, shown on west-to-east hydrogeologic cross section A-A', across the Pro-Ag Co-op property (vertically exaggerated). 


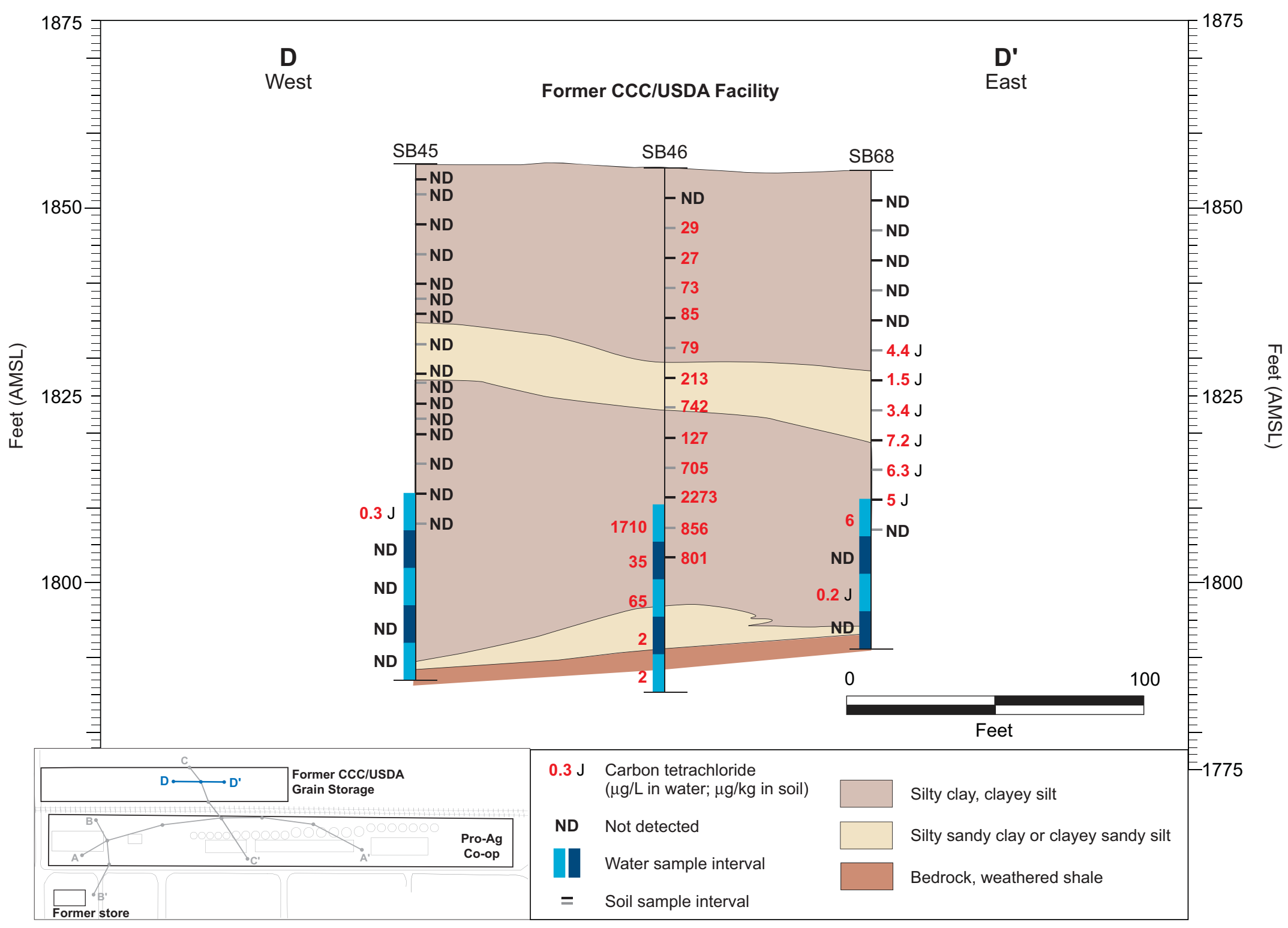

FIGURE 3.4 Horizontal and vertical distribution of carbon tetrachloride in soil and groundwater at Agra, shown on west-to-east hydrogeologic cross section D-D', on the former CCC/USDA facility (vertically exaggerated). 


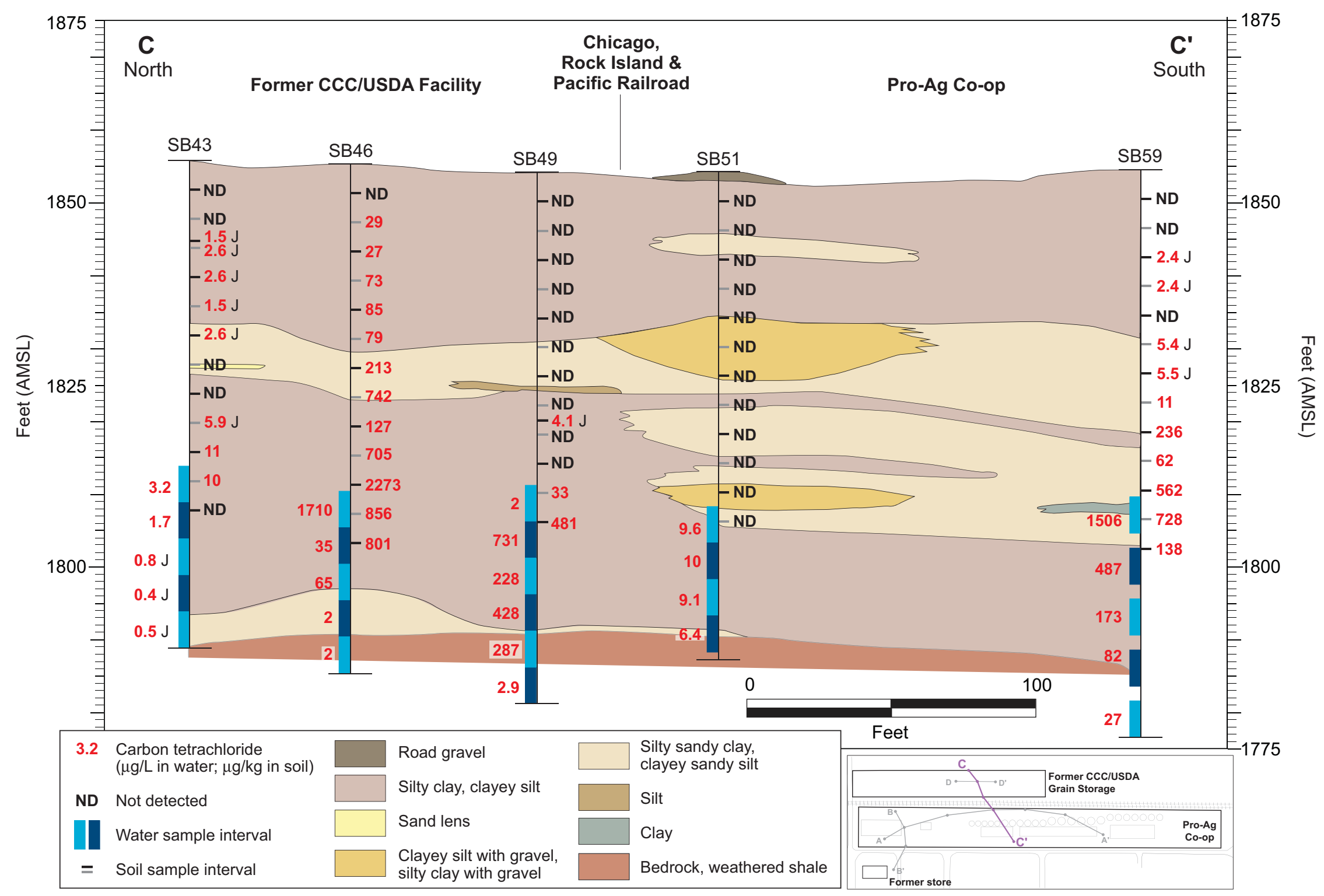

FIGURE 3.5 Horizontal and vertical distribution of carbon tetrachloride in soil and groundwater at Agra, shown on north-to-south hydrogeologic cross section C-C', across the former CCC/USDA facility and the Pro-Ag Co-op property (vertically exaggerated). 


\section{Proposed Source Control and Mass Removal Interim Measure}

The CCC/USDA proposes to obtain approval from the KDHE for this IM conceptual design and then, after a remediation contractor has been selected, submit an RDP that includes design specifications for KDHE review and approval.

The IM conceptual design proposed for implementation on the former CCC/USDA Agra property includes installation of LDBs coupled with SVE and AS systems (hereafter referred to as "LDB technology"). The CCC/USDA's goal is that the IM proposed here will become the final remedy.

The LDB technology proposed serves the following purposes:

- Physical removal of contaminated soil from the identified source areas.

- Volatilization of contaminants from portions of the affected aquifer that can be accessed from the former CCC/USDA property, achieved through placement of AS systems in the LDBs.

- Replacement of less permeable native materials (silty clay, clayey silt, and silty sand) with more permeable material(s) to facilitate the capture of volatilized contaminants in the vertical borehole.

- Removal of contaminants volatilized by AS and extracted from the vadose zone by SVE.

Upon approval of this IM conceptual design, the CCC/USDA intends to work with a remediation contractor to accomplish the following:

- Develop a detailed RDP for KDHE review.

- Obtain necessary permits for the remediation system, specifically for on-site disposal of contaminated soil through land farming and for releases of vapors and/or condensate. The KDHE Bureau of Water, Bureau of Air and Radiation, and Bureau of Waste Management will be contacted to determine which 
specific permits might be required. The required permits will be identified and discussed in the RDP.

- Install the remediation system and provide for the necessary O\&M and monitoring associated with the remediation system. 


\section{Interim Remedial Action Objectives}

The primary objectives of the IM proposed for the former CCC/USDA Agra property are as follows:

- Achieve source control for the inferred carbon tetrachloride contamination source.

- Accomplish mass removal of carbon tetrachloride from the vadose zone and the saturated zone.

- Eliminate the soil-to-groundwater pathway for carbon tetrachloride contamination by removing soil containing the contaminant at concentrations in excess of the RBSL of $200 \mu \mathrm{g} / \mathrm{kg}$ for the soil-to-groundwater protection pathway.

Successful implementation of the LDB technology on the former CCC/USDA Agra property will significantly reduce groundwater contaminant levels migrating from the site and eliminate the soil source of contamination originating at the former CCC/USDA property. The resulting benefits will be limited to the contaminant source on the former CCC/USDA site. The CCC/USDA strongly recommends that a source control measure also be implemented on the Pro-Ag Co-op property.

Potential implementation issues that have been identified include the following:

- Permission is needed for access to the property to conduct the full scope of work.

- Benefits of source remediation will be limited to the former CCC/USDA property if source control is not also implemented by the Pro-Ag Co-op on its property. 


\section{Interim Measure Design}

\subsection{Design Basis}

The LDB technology considered here involves a suite of remedial treatment operations, consisting of uniquely designed LDB installations with AS-SVE systems. When installed, singly or in combination, these remedial treatment operations have been shown to be practical and costeffective at numerous sites. For example, the concept of AS coupled with SVE appears to be commonly used for the remediation of dry cleaning sites in Kansas (http://www.drycleancoalition.org). This technology has also been used successfully at several petroleum-related sites throughout Kansas.

Conventional AS-SVE systems can be relied upon when the contamination scenario and the lithology of a site meet certain criteria. Specifically, the contaminant of concern must be volatile, and the lithology of the site should allow for the installation of a reasonable number of SVE wells to capture the contaminants mobilized by the AS component. Figure 6.1 depicts the relative impact of permeability and product volatility on the effectiveness of SVE, as evaluated on the basis of EPA (1995) guidance. Given the volatility of carbon tetrachloride, SVE is considered an effective technology.

Figure 6.1 further indicates that conventional SVE is considered moderately to minimally effective, given the permeability of the formations encountered at the former CCC/USDA Agra property (Section 3.2). However, investigators report that LDB technology has been used to overcome permeability constraints, maximize the radius of influence of the LDB-technologybased SVE point, and potentially increase the pore volume exchange rate within the expanded radius of influence (Tavener and Reetz [date unknown]).

Furthermore, LDB technology has the added advantage of the physical removal of large volumes of contaminated soil. LDB technology has been used at several sites in Kansas to address petroleum compounds and chlorinated solvents. Sites in Kansas where LDB technology has been deployed are summarized in Table 6.1.

The factors considered here - volatility, permeability, and physical removal of contaminated soil — point to the value of LDB technology as the design basis for the IM aimed at remediation of source area contamination at the former CCC/USDA Agra property. 
TABLE 6.1 Kansas sites where LDB technology has been deployed.

\begin{tabular}{|c|c|c|c|c|c|}
\hline Site & Contaminant & $\begin{array}{l}\text { Groundwater } \\
\text { Depth } \\
\text { (ft BGL) }\end{array}$ & Lithology & $\begin{array}{l}\text { LDB } \\
\text { Diameter } \\
\text { (ft) }\end{array}$ & $\begin{array}{c}\text { Year } \\
\text { Installed }\end{array}$ \\
\hline $\begin{array}{l}\text { Farmer's Co-op, } \\
\text { Alexander }\end{array}$ & Petroleum & $27-32$ & $\begin{array}{l}\text { Clay }(0-34 \mathrm{ft} \mathrm{BGL}) \text {, } \\
\text { underlain by fine-coarse } \\
\text { sand } \\
(32-35 \mathrm{ft} \mathrm{BGL})\end{array}$ & Unknown & 2003 \\
\hline Gaylord & Petroleum & $20-30$ & No drill logs available & Unknown & 2006 \\
\hline $\begin{array}{l}\text { Lawrence Battery, } \\
\text { Lawrence }\end{array}$ & Petroleum & $9-10$ & Clay underlain by sand & 3 & 2004 \\
\hline $\begin{array}{l}\text { This n That Lamb } \\
\text { Shop, Salina }\end{array}$ & Petroleum & $30-40$ & Clay underlain by sand & 3 & 2002 \\
\hline $\begin{array}{l}\text { Salina Central Garage, } \\
\text { Salina }\end{array}$ & Petroleum & 35 & $\begin{array}{l}\text { Silty clay, sandy clay, } \\
\text { silt to sand }\end{array}$ & 5 & 2003 \\
\hline $\begin{array}{l}501 \text { North Santa Fe, } \\
\text { Salina }\end{array}$ & $\begin{array}{l}\text { Carbon tetrachloride, } \\
\text { ethylene dibromide, } \\
\text { chlorinated aliphatics }\end{array}$ & $\begin{array}{l}\text { Approximately } \\
35-40\end{array}$ & $\begin{array}{l}\text { Silty clay, sandy clay, } \\
\text { silt to sand }\end{array}$ & 5 & 2006 \\
\hline
\end{tabular}

\subsection{Design Specifications}

The assumption made, for the purposes of this IM conceptual design, is that five 6-ftdiameter borings will be installed at the former CCC/USDA Agra property (Figure 6.2). The intended LDB design is depicted in Figure 6.3. The materials specified in Figure 6.3 for LDB construction, borehole diameters, screen length, well depths, well diameter, etc. are intended for reference only.

Although the design of the Agra LDB technology wells has not been finalized, each boring will likely be installed to a total depth of approximately $60 \mathrm{ft}$ BGL. Monitoring points for the installed remediation system will include existing monitoring wells MW-J and MW-Q; existing well MW-P, if it is not removed during installation of the remediation system; and five proposed new control point monitoring wells (Figure 6.2).

The locations proposed (Figure 6.2) for the LDBs are in areas where the removal of contaminated soil in the vadose zone will be accomplished as the borings are advanced. Installation of the five LDBs will result in the removal of approximately 314 cubic yards of contaminated soil. The contaminated soil will be land farmed on-site before it is incorporated 
into the top soil of the land farm site. The RDP will address permitting associated with the land farming operation.

An AS point and SVE well will be installed in each of the five LDBs installed at the site. Screen intervals, well diameters, and well depths reported here are tentative construction specifications. The RDP will include the final construction specifications. Conceptually, each AS well will be installed to a depth of approximately 55-60 ft BGL to ensure that the sparge point penetrates the saturated zone during droughts or periods of excessive pumping from off-site wells. An AS point will likely consist of a 2-in. air sparge well with an approximate 5-ft screen at the bottom. The SVE well will likely consist of a 4-in. well screened across the vadose zone that has been shown to contain the highest contaminant concentrations. As the AS and SVE wells are completed, the LDB will be backfilled with clean/washed gravel from total depth (approximately $60 \mathrm{ft}$ BGL) to 5-10 ft BGL. A layer of bentonite 6-12 in. thick will be placed over the sand, and the borehole will be backfilled with topsoil to a depth of $12 \mathrm{in.} \mathrm{BGL.}$

All five SVE and AS wells will be piped through trenches to a self-contained trailermounted, fully equipped remediation system. The exact location and configuration of the trenches and the self-contained trailer-mounter remediation system are unspecified at this time. In general, the remediation system will be configured for use in Class 1, Division 2 environments. This type of environment, as defined in the National Electrical Code (NEC) manual, includes areas that may contain flammable gases in quantities that could produce explosive or flammable mixtures; however, under normal operating conditions, flammable gases, vapors, and liquids; combustible dusts; and ignitable fibers and flyings are not likely to exist (NFPA 2005). The following equipment will be included in the system design:

- AS and SVE blowers

- Individual well manifolds

- Volume flow meters, pressure gauges, and sample ports on each well leg

- $\quad$ Safety switches and interlocks

- Explosion-proof heater and exhaust fan

- Tamper-proof control panel with remote operating and monitoring capabilities 
The RDP will address permitting for media (air and/or condensate) released from the remediation system.

\subsection{Drawings/Schematics}

The drawing/schematic for the proposed remediation system is in Figure 6.3.

\subsection{Cost Estimate}

Discussions of the CCC/USDA with experienced remediation contractors indicate that an LDB-technology-based remediation system can be installed at the former CCC/USDA Agra property for approximately $\$ 180,000$. Two years of associated O\&M by the contractor is estimated to cost approximately $\$ 37,000$.

\subsection{Detailed Working Schedule}

The proposed working schedule is shown in Table 6.2.

TABLE 6.2 Working schedule for remediation system installation.

\begin{tabular}{lc}
\hline \multicolumn{1}{c}{ Milestone } & Tentative Date \\
\hline Baseline - submission of conceptual design IM to the KDHE & Month $(x) 2007$ \\
$\begin{array}{l}\text { Selection of remediation contractor; } \\
\text { Submission of remedial design plan to the KDHE for approval }\end{array}$ & Month $(x+1) 2007$ \\
Installation of remediation system & Month $(x+3) 2007$ \\
Initiation of the two-year O\&M period & Month $(x+4) 2007$ \\
First O\&M report (quarterly submission) & Month $(x+5) 2007$ \\
\hline
\end{tabular}




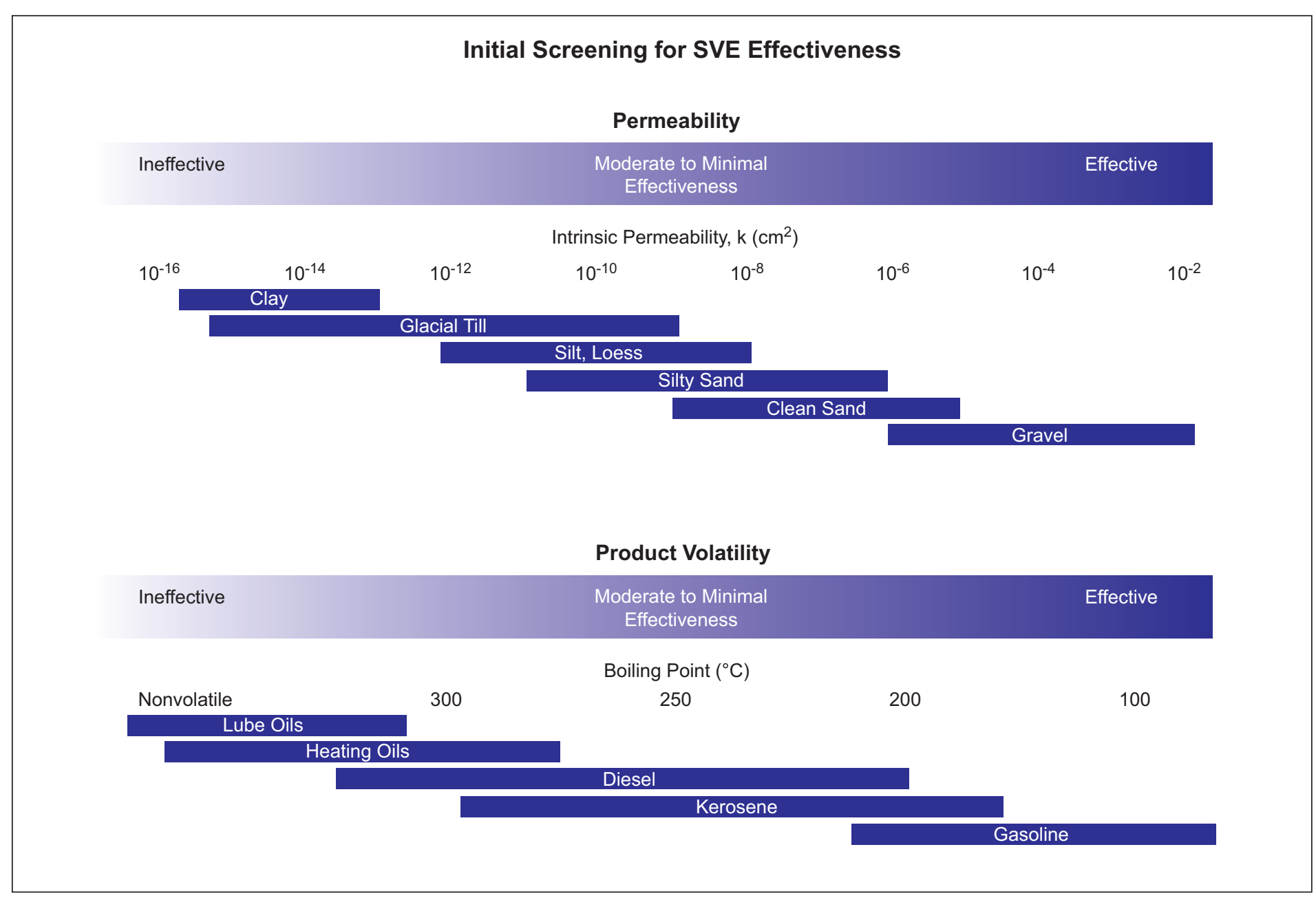

FIGURE 6.1 Initial screening for the effectiveness of LDB technology. Source of information: EPA (1995). 


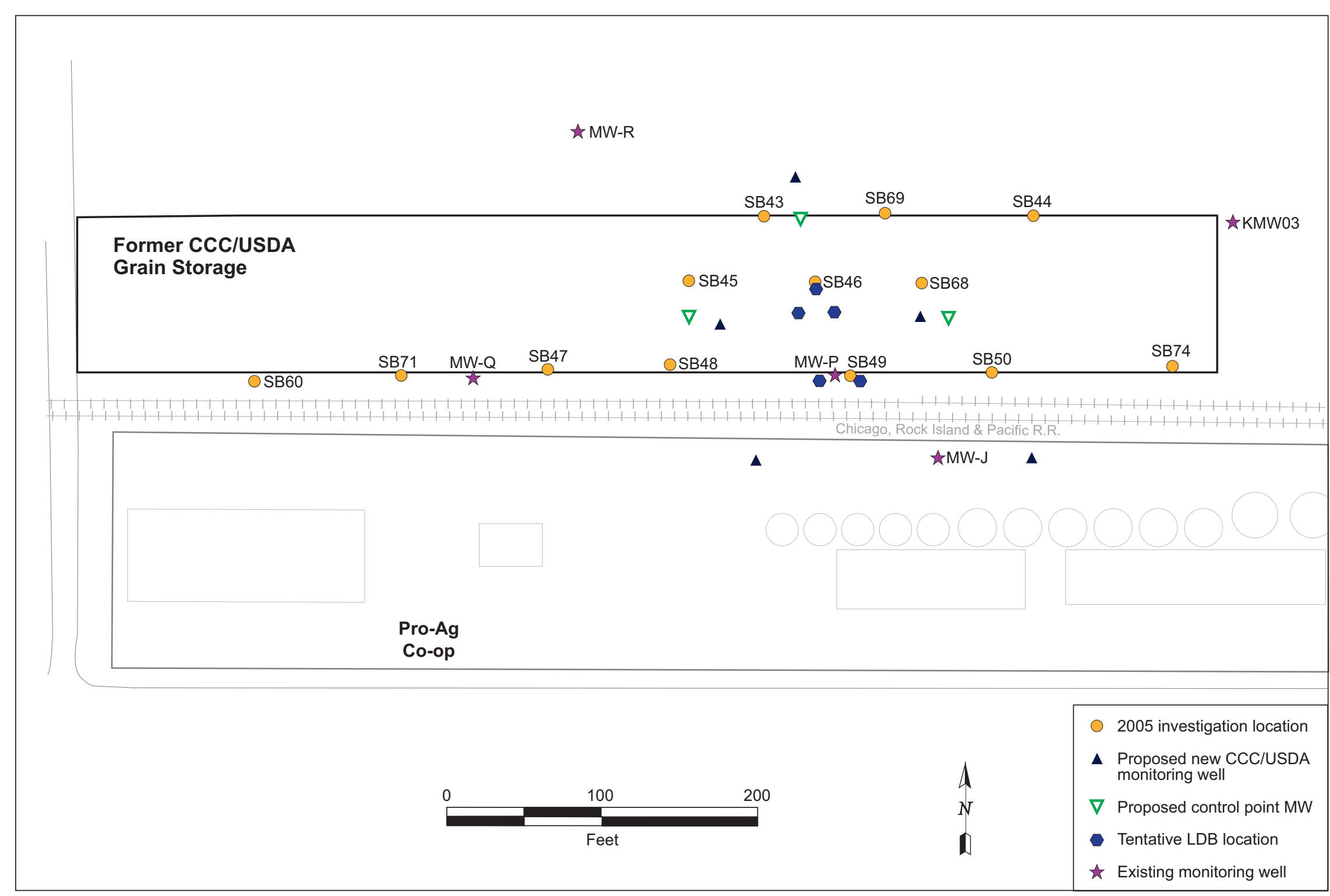




\section{Large Diameter Borehole (LDB) Conceptual Schematic Design}

\section{Agra, Kansas}

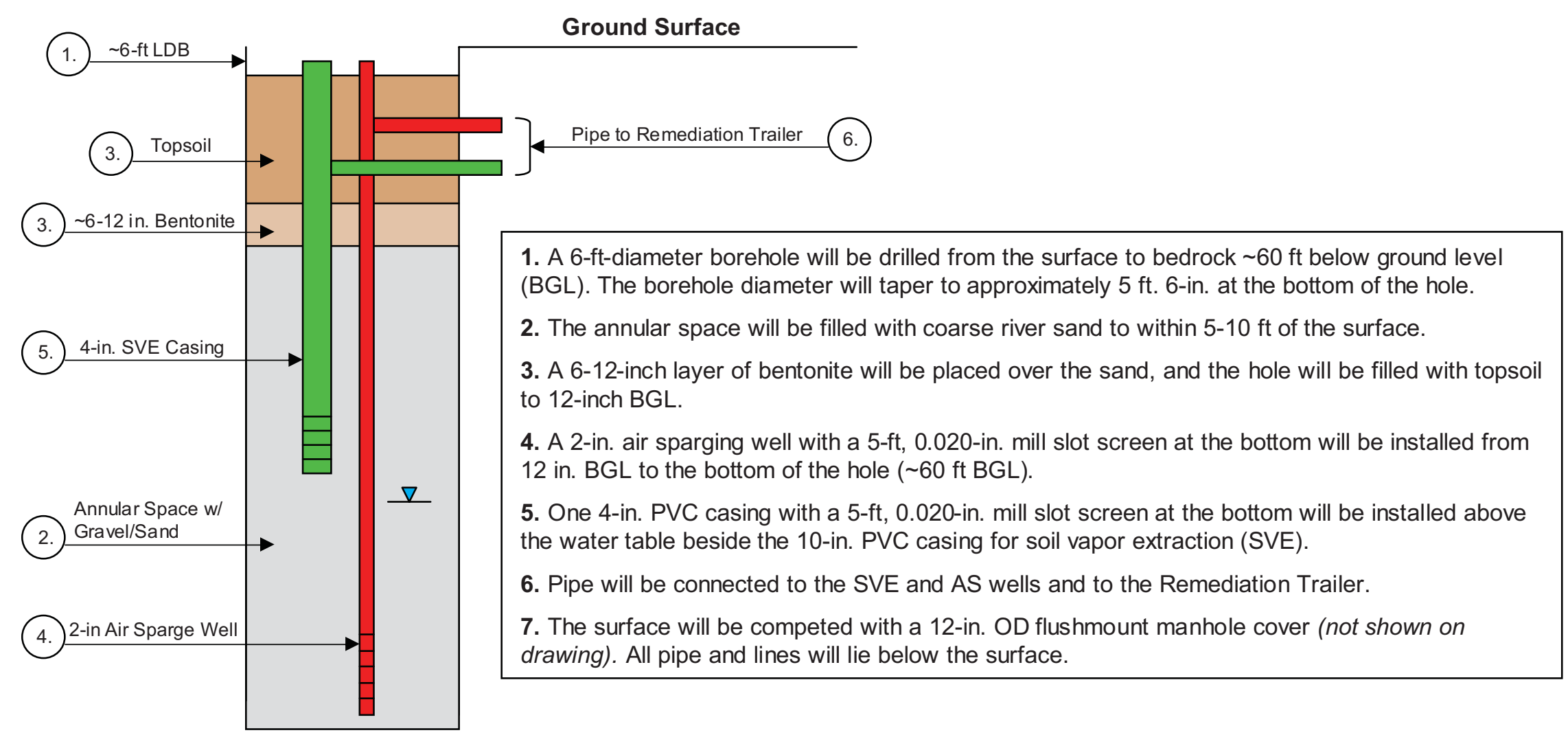

FIGURE 6.3 Proposed well design for an LDB installation with AS-SVE system at Agra (not to scale). 


\section{Status of RDP Appendices}

\subsection{RDP Appendix A: Data Acquisition Plan}

The Data Acquisition Plan will be provided with the RDP upon KDHE approval of the conceptual design.

\subsection{RDP Appendix B: Quality Assurance Project Plan}

The Quality Assurance Project Plan will be provided with the RDP upon KDHE approval of the conceptual design.

\subsection{RDP Appendix C: Treatability Study Testing Plan}

At this time, no treatability study activities are proposed.

\subsection{RDP Appendix D: Health and Safety Plan}

The Health and Safety Plan will be provided with the RDP upon KDHE approval of the conceptual design.

\subsection{RDP Appendix E: Operations and Maintenance Plan}

The Operations and Maintenance Plan will be provided with the RDP upon KDHE approval of the conceptual design. 


\section{References}

Argonne, 1995, Final Phase I Report and Phase II Work Plan: Expedited Site Characterization, Agra, Kansas, prepared for the Commodity Credit Corporation, U.S. Department of Agriculture, Washington, D.C., by Argonne National Laboratory, Argonne, Illinois, November.

Argonne, 1996, Final Report: Phase II Expedited Site Characterization, Agra, Kansas, prepared for the Commodity Credit Corporation, U.S. Department of Agriculture, Washington, D.C., by Argonne National Laboratory, Argonne, Illinois, May.

Argonne, 1997, Final Feasibility Study for Remedial Action at Agra, Kansas, prepared for the Commodity Credit Corporation, U.S. Department of Agriculture, Washington, D.C., by Argonne National Laboratory, Argonne, Illinois, June.

Argonne, 2006, Final Report: Results of the 2005 Investigation of Contaminant Sources at Agra, Kansas, ANL/EVS/AGEM/TR-06-02, prepared for the Commodity Credit Corporation, U.S. Department of Agriculture, Washington, D.C., by Argonne National Laboratory, Argonne, Illinois, July.

BE\&K/Terranext, 1998a, Phase I Corrective Action Study: Agra Public Water Supply, Agra, Kansas, prepared for the Kansas Department of Health and Environment, Topeka, Kansas, July 1.

BE\&K/Terranext, 1998b, Groundwater Monitoring Report: Agra Public Water Supply, Agra, Kansas, prepared for the Kansas Department of Health and Environment, Topeka, Kansas, November 5.

BE\&K/Terranext, 1999, Groundwater Monitoring Report: Agra Public Water Supply, Agra, Kansas, prepared for the Kansas Department of Health and Environment, Topeka, Kansas, June 16.

EPA, 1995, How to Evaluate Alternative Cleanup Tehnologies for Underground Storage Tank Sites: A Guide for Corrective Action Plan Reviewers, EPA-510-B-94-007, Office of Underground Storage Tanks, U.S. Environmental Protection Agency, Washington, D.C., May. 
Gotto, L. 2004, letter from Gotto (Bureau of Environmental Remediation, Kansas Department of Health and Environment, Topeka, Kansas) to C. Roe (Commodity Credit Corporation, U.S. Department of Agriculture, Washington, D.C.), regarding completion of the feasibility study for remedial action at Agra, March 1.

KDHE, 1985, letter from S. Patrick McCool (Bureau of Water Protection, Kansas Department of Health and Environment, Topeka, Kansas) to Agra, Kansas, mayor and city council, regarding analytical results for the sampling of Agra municipal water system wells PW01-PW04 on September 4, 1985, December 26.

KDHE, 1986, letter from S. Patrick McCool (Bureau of Water Protection, Kansas Department of Health and Environment, Topeka, Kansas) to Agra, Kansas, mayor and city council, regarding analytical results for the sampling of Agra municipal water system wells PWS-3 and PWS-4 in August 1986, requiring that these wells not be used for public water supply purposes, September 4.

KDHE, 1987, Preliminary Assessment Report for Agra Public Water Supply Wells \#3 and \#4, KSD981710262, Agra, Kansas 67621, Bureau of Environmental Remediation, Kansas Department of Health and Environment, Topeka, Kansas, December 15.

KDHE, 1988, Final Site Inspection for the Agra Public Water Supply Wells \#3 and \#4, KSD981710262, Agra, Kansas (Part 1), Bureau of Environmental Remediation, Kansas Department of Health and Environment, Topeka, Kansas, July 30.

KDHE, 1996, Policy and Scope of Work: Interim Measures, BER Policy \#BER-RS-029, Bureau of Environmental Remediation/Remedial Section, Kansas Department of Health and Environment, Topeka, Kansas, revised October 2006 (http://www.kdheks.gov/ber/policies/ BER_RS_029.pdf).

NFPA, 2005, NEC ${ }^{\circledR} 2005$ NFPA 70: National Electrical Code ${ }^{\circledR}$ (International Electrical Code ${ }^{\circledR}$ Series), National Fire Protection Association, Quincy, Massachusetts (http://www.nfpa.org/ index.asp). 
PRC, 1994, Final Site Assessment: Agra Public Water Supply Site, Agra, Phillips County, prepared for the Kansas Department of Health and Environment, Topeka, Kansas, by PRC Environmental Management, Inc., July 11.

PRC, 1995, Final Comprehensive Investigation of the Agra Public Water Supply Site, Agra, Phillips County, prepared for the Kansas Department of Health and Environment, Topeka, Kansas, by PRC Environmental Management, Inc., November 13.

Tavener, B., and B. Reetz, date unknown, Innovative Construction and Performance Monitoring of Soil Vapor Extraction and Air Sparging in Large Diameter Borings, presented at meeting of the National Ground Water Association.

USDA, 1961, aerial photograph AYY1BB-65, U.S. Department of Agriculture, Washington, D.C., August 23. 


\section{Appendix A:}

Summary of Analytical Results for Soil and Groundwater Samples Collected at Agra in 2005 
TABLE A.1 Summary of analytical results for soil samples collected on the former CCC/USDA property during the 2005 investigation at Agra, Kansas.

\begin{tabular}{|c|c|c|c|c|c|c|}
\hline \multirow[b]{2}{*}{ Location } & \multirow[b]{2}{*}{$\begin{array}{l}\text { Sample } \\
\text { Date }\end{array}$} & \multirow[b]{2}{*}{$\begin{array}{l}\text { Depth } \\
\text { (ft BGL) }\end{array}$} & \multirow[b]{2}{*}{$\begin{array}{c}\text { Number of } \\
\text { Samples }\end{array}$} & \multicolumn{3}{|c|}{ Concentration $(\mu \mathrm{g} / \mathrm{kg})$} \\
\hline & & & & $\begin{array}{c}\text { Carbon } \\
\text { Tetra- } \\
\text { chloride }\end{array}$ & $\begin{array}{l}\text { Chloro- } \\
\text { form }\end{array}$ & $\begin{array}{l}\text { 1,2-Dichloro- } \\
\text { ethane }\end{array}$ \\
\hline \multirow[t]{13}{*}{ SB43 } & $7 / 11 / 05$ & 4.0 & 1 & $N D^{a}$ & ND & ND \\
\hline & & 8.0 & 1 & ND & ND & ND \\
\hline & & 11.0 & 1 & $1.5 \mathrm{~J}^{\mathrm{b}}$ & ND & ND \\
\hline & & 12.0 & 1 & $2.6 \mathrm{~J}$ & $1.3 \mathrm{~J}$ & ND \\
\hline & & 16.0 & 1 & $2.6 \mathrm{~J}$ & ND & ND \\
\hline & & 20.0 & 1 & $1.5 \mathrm{~J}$ & $0.8 \mathrm{~J}$ & ND \\
\hline & & 24.0 & 1 & $2.6 \mathrm{~J}$ & $1.3 \mathrm{~J}$ & ND \\
\hline & & 28.0 & 1 & ND & ND & ND \\
\hline & & 32.0 & 1 & ND & ND & ND \\
\hline & & 36.0 & 1 & $5.9 \mathrm{~J}$ & ND & ND \\
\hline & & 40.0 & 1 & 11 & ND & ND \\
\hline & & 44.0 & 1 & 10 & $1.3 \mathrm{~J}$ & ND \\
\hline & & 48.0 & 1 & ND & ND & ND \\
\hline SB45 & $7 / 11 / 05$ & $2.0-48.0$ & 16 & ND & ND & ND \\
\hline \multirow[t]{13}{*}{ SB46 } & $7 / 10 / 05$ & 4.0 & 1 & ND & ND & ND \\
\hline & & 8.0 & 1 & 29 & $5.7 \mathrm{~J}$ & ND \\
\hline & & 12.0 & 1 & 27 & $3.6 \mathrm{~J}$ & ND \\
\hline & & 16.0 & 1 & 73 & $1.2 \mathrm{~J}$ & ND \\
\hline & & 20.0 & 1 & 85 & 11 & ND \\
\hline & & 24.0 & 1 & 79 & 13 & ND \\
\hline & & 28.0 & 1 & 213 & 17 & ND \\
\hline & & 32.0 & 1 & 742 & 10 & ND \\
\hline & & 36.0 & 1 & 127 & 10 & ND \\
\hline & & 40.0 & 1 & 705 & $8.3 \mathrm{~J}$ & ND \\
\hline & & 44.0 & 1 & 2,273 & $7.7 \mathrm{~J}$ & ND \\
\hline & & 48.0 & 1 & 856 & 17 & ND \\
\hline & & 52.0 & 1 & 801 & $2.0 \mathrm{~J}$ & ND \\
\hline SB48 & $\begin{array}{r}7 / 12 / 05- \\
7 / 13 / 05\end{array}$ & $4.0-48.0$ & 12 & ND & ND & ND \\
\hline \multirow[t]{10}{*}{ SB49 } & $7 / 12 / 05$ & 4.0 & 1 & ND & ND & ND \\
\hline & & 8.0 & 1 & ND & $0.3 \mathrm{~J}$ & ND \\
\hline & & 12.0 & 1 & ND & ND & ND \\
\hline & & 16.0 & 1 & ND & $0.9 \mathrm{~J}$ & ND \\
\hline & & $20.0-32.0$ & 4 & ND & ND & ND \\
\hline & & 34.0 & 1 & $4.1 \mathrm{~J}$ & ND & ND \\
\hline & & 36.0 & 1 & ND & ND & ND \\
\hline & & 40.0 & 1 & ND & ND & ND \\
\hline & & 44.0 & 1 & 33 & ND & ND \\
\hline & & 48.0 & 1 & 481 & $8.5 \mathrm{~J}$ & ND \\
\hline
\end{tabular}


TABLE A.1 (Cont.)

\begin{tabular}{|c|c|c|c|c|c|c|}
\hline \multirow[b]{2}{*}{ Location } & \multirow[b]{2}{*}{$\begin{array}{l}\text { Sample } \\
\text { Date }\end{array}$} & \multirow[b]{2}{*}{$\begin{array}{l}\text { Depth } \\
\text { (ft BGL) }\end{array}$} & \multirow[b]{2}{*}{$\begin{array}{c}\text { Number of } \\
\text { Samples }\end{array}$} & \multicolumn{3}{|c|}{ Concentration $(\mu \mathrm{g} / \mathrm{kg})$} \\
\hline & & & & $\begin{array}{l}\text { Carbon } \\
\text { Tetra- } \\
\text { chloride }\end{array}$ & $\begin{array}{l}\text { Chloro- } \\
\text { form }\end{array}$ & $\begin{array}{l}\text { 1,2-Dichloro- } \\
\text { ethane }\end{array}$ \\
\hline \multirow[t]{11}{*}{ SB68 } & $7 / 13 / 05$ & $4.0-8.0$ & 2 & ND & ND & ND \\
\hline & & 12.0 & 1 & ND & $1.8 \mathrm{~J}$ & ND \\
\hline & & 16.0 & 1 & ND & $1.6 \mathrm{~J}$ & ND \\
\hline & & 20.0 & 1 & ND & ND & ND \\
\hline & & 24.0 & 1 & $4.4 \mathrm{~J}$ & $2.7 \mathrm{~J}$ & ND \\
\hline & & 28.0 & 1 & $1.5 \mathrm{~J}$ & ND & ND \\
\hline & & 32.0 & 1 & $3.4 \mathrm{~J}$ & $2.3 \mathrm{~J}$ & ND \\
\hline & & 36.0 & 1 & $7.2 \mathrm{~J}$ & $1.7 \mathrm{~J}$ & ND \\
\hline & & 40.0 & 1 & $6.3 \mathrm{~J}$ & $1.4 \mathrm{~J}$ & ND \\
\hline & & 44.0 & 1 & $5.0 \mathrm{~J}$ & ND & ND \\
\hline & & 48.0 & 1 & ND & ND & ND \\
\hline
\end{tabular}

a ND, contaminant not detected at a detection limit of $1.0 \mu \mathrm{g} / \mathrm{kg}$.

b Qualifier J indicates an estimated concentration below the quantitation limit of $10.0 \mu \mathrm{g} / \mathrm{kg}$. 
TABLE A.2 Summary of analytical results for soil samples collected on and near the Pro-Ag Co-op property during the 2005 investigation at Agra, Kansas.

\begin{tabular}{|c|c|c|c|c|c|c|}
\hline \multirow[b]{2}{*}{ Location } & \multirow[b]{2}{*}{$\begin{array}{l}\text { Sample } \\
\text { Date }\end{array}$} & \multirow[b]{2}{*}{$\begin{array}{l}\text { Depth } \\
\text { (ft BGL) }\end{array}$} & \multirow[b]{2}{*}{$\begin{array}{c}\text { Number of } \\
\text { Samples }\end{array}$} & \multicolumn{3}{|c|}{ Concentration $(\mu \mathrm{g} / \mathrm{kg})$} \\
\hline & & & & $\begin{array}{c}\text { Carbon } \\
\text { Tetra- } \\
\text { chloride }\end{array}$ & $\begin{array}{l}\text { Chloro- } \\
\text { form }\end{array}$ & $\begin{array}{l}\text { 1,2-Dichloro- } \\
\text { ethane }\end{array}$ \\
\hline SB51 & $5 / 23 / 05$ & $4.0-48.0$ & 12 & $N D^{a}$ & ND & ND \\
\hline SB52 & $5 / 21 / 05$ & $4.0-46.0$ & 13 & ND & ND & ND \\
\hline \multirow[t]{6}{*}{ SB53 } & $5 / 20 / 05$ & 4.0 & 1 & ND & ND & ND \\
\hline & & 8.0 & 1 & ND & ND & ND \\
\hline & & 12.0 & 1 & 16 & $2.1 \mathrm{~J}^{\mathrm{b}}$ & ND \\
\hline & & $16.0-32.0$ & 6 & ND & ND & ND \\
\hline & & 36.0 & 1 & 10 & $3.4 \mathrm{~J}$ & ND \\
\hline & & 40.0 & 1 & 52 & $5.9 \mathrm{~J}$ & $5.9 \mathrm{~J}$ \\
\hline SB54 & $6 / 7 / 05$ & $4.0-44.0$ & 11 & ND & ND & ND \\
\hline \multirow[t]{3}{*}{ SB55 } & $6 / 3 / 05$ & $4.0-37.0$ & 10 & ND & ND & ND \\
\hline & & 41.0 & 1 & ND & $4.0 \mathrm{~J}$ & ND \\
\hline & & 45.0 & 1 & ND & ND & ND \\
\hline \multirow[t]{3}{*}{ SB56 } & $5 / 26 / 05$ & $4.0-36.0$ & 9 & ND & ND & ND \\
\hline & & 40.0 & 1 & ND & $4.1 \mathrm{~J}$ & ND \\
\hline & & $44.0-48.0$ & 2 & ND & ND & ND \\
\hline \multirow[t]{3}{*}{ SB58 } & $5 / 22 / 05$ & $4.0-24.0$ & 6 & ND & ND & ND \\
\hline & & 28.0 & 1 & $2.1 \mathrm{~J}$ & ND & ND \\
\hline & & $32.0-48.0$ & 5 & ND & ND & ND \\
\hline \multirow[t]{12}{*}{ SB59 } & 6/6/05 & $4.0-8.0$ & 2 & ND & ND & ND \\
\hline & & 12.0 & 1 & $2.4 \mathrm{~J}$ & $1.4 \mathrm{~J}$ & ND \\
\hline & & 16.0 & 1 & $2.4 \mathrm{~J}$ & ND & ND \\
\hline & & 20.0 & 1 & ND & ND & ND \\
\hline & & 24.0 & 1 & $5.4 \mathrm{~J}$ & $1.9 \mathrm{~J}$ & ND \\
\hline & & 28.0 & 1 & $5.5 \mathrm{~J}$ & $2.0 \mathrm{~J}$ & ND \\
\hline & & 32.0 & 1 & 11 & $2.8 \mathrm{~J}$ & ND \\
\hline & & 36.0 & 1 & 236 & $5.5 \mathrm{~J}$ & ND \\
\hline & & 40.0 & 1 & 62 & $6.0 \mathrm{~J}$ & ND \\
\hline & & 44.0 & 1 & 562 & $6.4 \mathrm{~J}$ & ND \\
\hline & & 48.0 & 1 & 728 & $5.0 \mathrm{~J}$ & ND \\
\hline & & 52.0 & 1 & 138 & $3.4 \mathrm{~J}$ & ND \\
\hline SB61 & $6 / 4 / 05$ & $4.0-40.0$ & 10 & ND & ND & ND \\
\hline \multirow[t]{4}{*}{ SB62 } & $5 / 24 / 05$ & $4.0-36.0$ & 9 & ND & ND & ND \\
\hline & & 40.0 & 1 & $6.2 \mathrm{~J}$ & $1.1 \mathrm{~J}$ & ND \\
\hline & & 44.0 & 1 & $1.9 \mathrm{~J}$ & ND & ND \\
\hline & & 48.0 & 1 & $3.4 \mathrm{~J}$ & ND & ND \\
\hline \multirow[t]{3}{*}{ SB63 } & $5 / 18 / 05-$ & 2.0 & 1 & ND & ND & ND \\
\hline & 5/19/05 & 4.0 & 1 & $2.7 \mathrm{~J}$ & $1.5 \mathrm{~J}$ & ND \\
\hline & & $5.0-44.0$ & 15 & ND & ND & ND \\
\hline
\end{tabular}


TABLE A.2 (Cont.)

\begin{tabular}{|c|c|c|c|c|c|c|}
\hline \multirow[b]{2}{*}{ Location } & \multirow[b]{2}{*}{$\begin{array}{l}\text { Sample } \\
\text { Date }\end{array}$} & \multirow[b]{2}{*}{$\begin{array}{l}\text { Depth } \\
\text { (ft BGL) }\end{array}$} & \multirow[b]{2}{*}{$\begin{array}{c}\text { Number of } \\
\text { Samples }\end{array}$} & \multicolumn{3}{|c|}{ Concentration $(\mu \mathrm{g} / \mathrm{kg})$} \\
\hline & & & & $\begin{array}{l}\text { Carbon } \\
\text { Tetra- } \\
\text { chloride }\end{array}$ & $\begin{array}{l}\text { Chloro- } \\
\text { form }\end{array}$ & $\begin{array}{l}\text { 1,2-Dichloro- } \\
\text { ethane }\end{array}$ \\
\hline \multirow[t]{10}{*}{ SB64 } & 6/12/05- & 4.0 & 1 & $3.1 \mathrm{~J}$ & ND & ND \\
\hline & 6/13/05 & 8.0 & 1 & ND & ND & ND \\
\hline & & 12.0 & 1 & $1.9 \mathrm{~J}$ & ND & ND \\
\hline & & $16.0-24.0$ & 3 & ND & ND & ND \\
\hline & & 28.0 & 1 & $3.4 \mathrm{~J}$ & ND & ND \\
\hline & & 32.0 & 1 & 19 & $1.8 \mathrm{~J}$ & ND \\
\hline & & 36.0 & 1 & 14 & ND & ND \\
\hline & & 40.0 & 1 & 140 & $3.0 \mathrm{~J}$ & ND \\
\hline & & 44.0 & 1 & 375 & $9.2 \mathrm{~J}$ & ND \\
\hline & & 48.0 & 1 & 1,604 & $4.2 \mathrm{~J}$ & ND \\
\hline SB73 & $6 / 13 / 05$ & $4.0-48.0$ & 12 & ND & ND & ND \\
\hline
\end{tabular}

a ND, contaminant not detected at a detection limit of $1.0 \mu \mathrm{g} / \mathrm{kg}$.

b Qualifier J indicates an estimated concentration below the quantitation limit of $10.0 \mu \mathrm{g} / \mathrm{kg}$. 
TABLE A.3 Summary of analytical results for soil samples collected at and near the former retail store during the 2005 investigation at Agra, Kansas.

\begin{tabular}{|c|c|c|c|c|c|c|}
\hline \multirow[b]{2}{*}{ Location } & \multirow[b]{2}{*}{$\begin{array}{l}\text { Sample } \\
\text { Date }\end{array}$} & \multirow[b]{2}{*}{$\begin{array}{l}\text { Depth } \\
\text { (ft BGL) }\end{array}$} & \multirow[b]{2}{*}{$\begin{array}{c}\text { Number of } \\
\text { Samples }\end{array}$} & \multicolumn{3}{|c|}{ Concentration $(\mu \mathrm{g} / \mathrm{kg})$} \\
\hline & & & & $\begin{array}{l}\text { Carbon } \\
\text { Tetra- } \\
\text { chloride }\end{array}$ & $\begin{array}{l}\text { Chloro- } \\
\text { form }\end{array}$ & $\begin{array}{l}\text { 1,2-Dichloro- } \\
\text { ethane }\end{array}$ \\
\hline \multirow[t]{3}{*}{ SB67 } & $7 / 14 / 05$ & $4.0-40.0$ & 10 & $N D^{a}$ & ND & ND \\
\hline & & 44.0 & 1 & $8.2 \mathrm{Jb}^{\mathrm{b}}$ & ND & ND \\
\hline & & 48.0 & 1 & 47 & ND & ND \\
\hline
\end{tabular}

a ND, contaminant not detected at a detection limit of $1.0 \mu \mathrm{g} / \mathrm{kg}$.

b Qualifier J indicates an estimated concentration below the quantitation limit of $10.0 \mu \mathrm{g} / \mathrm{kg}$. 
TABLE A.4 Summary of results of organic analyses on groundwater samples collected on the former CCC/USDA property during the 2005 investigation at Agra, Kansas. ${ }^{a}$

\begin{tabular}{|c|c|c|c|c|c|c|c|}
\hline \multirow[b]{2}{*}{ Location } & \multirow[b]{2}{*}{$\begin{array}{l}\text { Sample } \\
\text { Date }\end{array}$} & \multirow[b]{2}{*}{$\begin{array}{l}\text { Sample } \\
\text { Type }^{b}\end{array}$} & \multirow[b]{2}{*}{$\begin{array}{c}\text { Depth } \\
\text { (ft BGL) }\end{array}$} & \multirow[b]{2}{*}{$\begin{array}{l}\text { Number of } \\
\text { Samples }\end{array}$} & \multicolumn{3}{|c|}{ Concentration $(\mu \mathrm{g} / \mathrm{L})$} \\
\hline & & & & & $\begin{array}{l}\text { Carbon } \\
\text { Tetra- } \\
\text { chloride }\end{array}$ & $\begin{array}{l}\text { Chloro- } \\
\text { form }\end{array}$ & $\begin{array}{l}\text { 1,2-Dichloro- } \\
\text { ethane }\end{array}$ \\
\hline KMW03 & $5 / 21 / 05$ & MW & $74-89$ & 1 & $N D^{c}$ & ND & ND \\
\hline MW-P & $6 / 13 / 05$ & $\mathrm{MW}$ & $35.42-54.92$ & 1 & 423 & 3.5 & ND \\
\hline MW-Q & $5 / 21 / 05$ & MW & $43.28-62.78$ & 1 & $0.5 \mathrm{~J}^{\mathrm{d}}$ & ND & ND \\
\hline SB43 & $7 / 11 / 05$ & CPT & $\begin{array}{l}42-47 \\
47-52 \\
52-57 \\
57-62 \\
62-67\end{array}$ & $\begin{array}{l}1 \\
1 \\
1 \\
1 \\
1\end{array}$ & $\begin{array}{l}3.2 \\
1.7 \\
0.8 \mathrm{~J} \\
0.4 \mathrm{~J} \\
0.5 \mathrm{~J}\end{array}$ & $\begin{array}{l}0.8 \mathrm{~J} \\
0.3 \mathrm{~J} \\
N D \\
N D \\
N D\end{array}$ & $\begin{array}{l}\text { ND } \\
\text { ND } \\
\text { ND } \\
\text { ND } \\
\text { ND }\end{array}$ \\
\hline SB44 & $7 / 10 / 05$ & СРТ & $53.5-58.5$ & 1 & ND & ND & ND \\
\hline SB45 & $\begin{array}{l}7 / 8 / 05 \\
7 / 7 / 05\end{array}$ & CPT & $\begin{array}{l}44-49 \\
49-69\end{array}$ & $\begin{array}{l}1 \\
4\end{array}$ & $\begin{array}{l}0.3 \mathrm{~J} \\
\mathrm{ND}\end{array}$ & $\begin{array}{l}0.2 \mathrm{~J} \\
\mathrm{ND}\end{array}$ & $\begin{array}{l}\text { ND } \\
\text { ND }\end{array}$ \\
\hline SB46 & $7 / 6 / 05$ & CPT & $\begin{array}{l}45-50 \\
50-55 \\
55-60 \\
60-65 \\
65-70\end{array}$ & $\begin{array}{l}1 \\
1 \\
1 \\
1 \\
1\end{array}$ & $\begin{array}{c}1,710 \\
35 \\
65 \\
2.0 \\
2.0\end{array}$ & $\begin{array}{l}49 \\
2.1 \\
4.6 \\
0.4 \mathrm{~J} \\
0.4 \mathrm{~J}\end{array}$ & $\begin{array}{l}\text { ND } \\
\text { ND } \\
\text { ND } \\
\text { ND } \\
\text { ND }\end{array}$ \\
\hline SB47 & $6 / 11 / 05$ & СРТ & $\begin{array}{c}44.5-49.5 \\
49.5-54.5 \\
54.5-59.5 \\
59.5-64.5 \\
64.5-69.5 \\
67-72\end{array}$ & $\begin{array}{l}1 \\
1 \\
1 \\
1 \\
1 \\
1\end{array}$ & $\begin{array}{l}0.4 \mathrm{~J} \\
\mathrm{ND} \\
0.9 \mathrm{~J} \\
0.3 \mathrm{~J} \\
0.3 \mathrm{~J} \\
\mathrm{ND}\end{array}$ & $\begin{array}{l}\text { ND } \\
\text { ND } \\
\text { ND } \\
\text { ND } \\
\text { ND } \\
\text { ND }\end{array}$ & $\begin{array}{l}\text { ND } \\
\text { ND } \\
\text { ND } \\
\text { ND } \\
\text { ND } \\
\text { ND }\end{array}$ \\
\hline SB48 & $\begin{array}{r}6 / 12 / 05- \\
6 / 13 / 05\end{array}$ & СРТ & $\begin{array}{l}45.5-50.5 \\
50.5-55.5 \\
55.5-60.5 \\
60.5-65.5 \\
65.5-70.5\end{array}$ & $\begin{array}{l}1 \\
1 \\
1 \\
1 \\
1\end{array}$ & $\begin{array}{c}35 \\
8.5 \\
23 \\
76 \\
2.3\end{array}$ & $\begin{array}{l}1.4 \\
1.1 \\
1.7 \\
2.8 \\
1.0\end{array}$ & $\begin{array}{l}\text { ND } \\
\text { ND } \\
\text { ND } \\
\text { ND } \\
\text { ND }\end{array}$ \\
\hline SB49 & $6 / 13 / 05$ & СРТ & $\begin{array}{l}43-48 \\
48-53 \\
53-58 \\
58-63 \\
63-68 \\
68-73\end{array}$ & $\begin{array}{l}1 \\
1 \\
1 \\
1 \\
1 \\
1\end{array}$ & $\begin{array}{c}2.0 \\
731 \\
228 \\
428 \\
287 \\
2.9\end{array}$ & $\begin{array}{l}\text { ND } \\
5.5 \\
2.3 \\
4.5 \\
3.2 \\
\text { ND }\end{array}$ & $\begin{array}{l}\text { ND } \\
\text { ND } \\
\text { ND } \\
\text { ND } \\
\text { ND } \\
\text { ND }\end{array}$ \\
\hline SB50 & 6/13/05 & CPT & $45.5-65.5$ & 4 & ND & ND & ND \\
\hline SB60 & 6/10/05 & CPT & $\begin{array}{l}41-46 \\
46-67\end{array}$ & $\begin{array}{l}1 \\
4\end{array}$ & $\begin{array}{l}0.4 \mathrm{~J} \\
\mathrm{ND}\end{array}$ & $\begin{array}{l}0.5 \mathrm{~J} \\
\mathrm{ND}\end{array}$ & $\begin{array}{l}\text { ND } \\
\text { ND }\end{array}$ \\
\hline
\end{tabular}


TABLE A.4 (Cont.)

\begin{tabular}{|c|c|c|c|c|c|c|c|}
\hline \multirow[b]{2}{*}{ Location } & \multirow[b]{2}{*}{$\begin{array}{l}\text { Sample } \\
\text { Date }\end{array}$} & \multirow[b]{2}{*}{$\begin{array}{l}\text { Sample } \\
\text { Type }^{\text {b }}\end{array}$} & \multirow[b]{2}{*}{$\begin{array}{l}\text { Depth } \\
\text { (ft BGL) }\end{array}$} & \multirow[b]{2}{*}{$\begin{array}{l}\text { Number of } \\
\text { Samples }\end{array}$} & \multicolumn{3}{|c|}{ Concentration $(\mu \mathrm{g} / \mathrm{L})$} \\
\hline & & & & & $\begin{array}{c}\text { Carbon } \\
\text { Tetra- } \\
\text { chloride }\end{array}$ & $\begin{array}{l}\text { Chloro- } \\
\text { form }\end{array}$ & $\begin{array}{l}\text { 1,2-Dichloro- } \\
\text { ethane }\end{array}$ \\
\hline SB68 & $7 / 10 / 05$ & СРТ & $\begin{array}{l}44-49 \\
49-54 \\
54-59 \\
59-64\end{array}$ & $\begin{array}{l}1 \\
1 \\
1 \\
1\end{array}$ & $\begin{array}{l}6.0 \\
\text { ND } \\
0.2 \mathrm{~J} \\
\mathrm{ND}\end{array}$ & $\begin{array}{l}0.4 \mathrm{~J} \\
\mathrm{ND} \\
\mathrm{ND} \\
\mathrm{ND}\end{array}$ & $\begin{array}{l}\text { ND } \\
\text { ND } \\
\text { ND } \\
\text { ND }\end{array}$ \\
\hline SB69 & $7 / 8 / 05$ & СРТ & $\begin{array}{l}49-54 \\
54-59 \\
59-64\end{array}$ & $\begin{array}{l}1 \\
1 \\
1\end{array}$ & $\begin{array}{l}0.5 \mathrm{~J} \\
1.0 \\
\text { ND }\end{array}$ & $\begin{array}{l}\text { ND } \\
\text { ND } \\
\text { ND }\end{array}$ & $\begin{array}{l}\text { ND } \\
\text { ND } \\
\text { ND }\end{array}$ \\
\hline SB71 & $6 / 11 / 05$ & СРТ & $\begin{array}{l}47-52 \\
52-57 \\
57-62 \\
62-77\end{array}$ & $\begin{array}{l}1 \\
1 \\
1 \\
3\end{array}$ & $\begin{array}{l}2.1 \\
0.2 \mathrm{~J} \\
0.9 \mathrm{~J} \\
\mathrm{ND}\end{array}$ & $\begin{array}{l}0.7 \mathrm{~J} \\
\mathrm{ND} \\
\mathrm{ND} \\
\mathrm{ND}\end{array}$ & $\begin{array}{l}\text { ND } \\
\text { ND } \\
\text { ND } \\
\text { ND }\end{array}$ \\
\hline
\end{tabular}

a Methylene chloride was not detected in any of these samples at a method detection limit of $0.1 \mu \mathrm{g} / \mathrm{L}$.

b Sample types: CPT, cone penetrometer; MW, monitoring well.

c ND, contaminant not detected at detection limit of $0.1 \mu \mathrm{g} / \mathrm{L}$.

d Qualifier J indicates an estimated concentration below the quantitation limit of $1.0 \mu \mathrm{g} / \mathrm{L}$. 
TABLE A.5 Summary of results of organic analyses on groundwater samples collected on and near the Pro-Ag Co-op property during the 2005 investigation at Agra, Kansas. ${ }^{a}$

\begin{tabular}{|c|c|c|c|c|c|c|c|}
\hline \multirow[b]{2}{*}{ Location } & \multirow[b]{2}{*}{$\begin{array}{l}\text { Sample } \\
\text { Date }\end{array}$} & \multirow[b]{2}{*}{$\begin{array}{l}\text { Sample } \\
\text { Type }^{\text {b }}\end{array}$} & \multirow[b]{2}{*}{$\begin{array}{c}\text { Depth } \\
\text { (ft BGL) }\end{array}$} & \multirow[b]{2}{*}{$\begin{array}{l}\text { Number of } \\
\text { Samples }\end{array}$} & \multicolumn{3}{|c|}{ Concentration $(\mu \mathrm{g} / \mathrm{L})$} \\
\hline & & & & & $\begin{array}{l}\text { Carbon } \\
\text { Tetra- } \\
\text { chloride }\end{array}$ & $\begin{array}{l}\text { Chloro- } \\
\text { form }\end{array}$ & $\begin{array}{l}\text { 1,2-Dichloro- } \\
\text { ethane }\end{array}$ \\
\hline KMW02 & $5 / 19 / 05$ & MW & $57-97$ & 1 & $0.4 \mathrm{~J}^{\mathrm{c}}$ & $0.3 \mathrm{~J}$ & $N D^{d}$ \\
\hline MW-H & $5 / 25 / 05$ & MW & $43-53$ & 1 & ND & $0.7 \mathrm{~J}$ & ND \\
\hline MW-I & $5 / 19 / 05$ & MW & $36-71$ & 1 & $0.2 \mathrm{~J}$ & ND & ND \\
\hline MW-J & $5 / 21 / 05$ & MW & $56-66$ & 1 & 13 & ND & ND \\
\hline MW-K & $5 / 21 / 05$ & MW & $55-65$ & 1 & ND & ND & ND \\
\hline MW-O & $5 / 22 / 05$ & MW & $38-58$ & 1 & $0.9 \mathrm{~J}$ & ND & ND \\
\hline SB51 & $\begin{array}{r}5 / 23 / 05- \\
5 / 24 / 05\end{array}$ & СPT & $\begin{array}{l}46-51 \\
51-56 \\
56-61 \\
61-66\end{array}$ & $\begin{array}{l}1 \\
1 \\
1 \\
1\end{array}$ & $\begin{array}{c}9.6 \\
10 \\
9.1 \\
6.4\end{array}$ & $\begin{array}{l}0.3 \mathrm{~J} \\
0.5 \mathrm{~J} \\
\mathrm{ND} \\
\mathrm{ND}\end{array}$ & $\begin{array}{l}\text { ND } \\
\text { ND } \\
\text { ND } \\
\text { ND }\end{array}$ \\
\hline SB52 & $5 / 22 / 05$ & CPT & $\begin{array}{c}44-49 \\
49-54 \\
54-59 \\
59-68.45\end{array}$ & $\begin{array}{l}1 \\
1 \\
1 \\
2\end{array}$ & $\begin{array}{l}\text { ND } \\
0.4 \mathrm{~J} \\
0.7 \mathrm{~J} \\
\mathrm{ND}\end{array}$ & $\begin{array}{l}\text { ND } \\
\text { ND } \\
0.3 \mathrm{~J} \\
\mathrm{ND}\end{array}$ & $\begin{array}{l}\text { ND } \\
\text { ND } \\
\text { ND } \\
\text { ND }\end{array}$ \\
\hline SB53 & $\begin{array}{r}5 / 20 / 05- \\
5 / 21 / 05\end{array}$ & CPT & $\begin{array}{l}48-53 \\
53-58 \\
58-63 \\
63-68\end{array}$ & $\begin{array}{l}1 \\
1 \\
1 \\
1\end{array}$ & $\begin{array}{r}294 \\
168 \\
350 \\
5.4\end{array}$ & $\begin{array}{l}18 \\
11 \\
14 \\
0.9 \mathrm{~J}\end{array}$ & $\begin{array}{l}3.0 \\
\text { ND } \\
1.3 \\
\text { ND }\end{array}$ \\
\hline SB54 & $\begin{array}{r}\text { 6/8/05- } \\
6 / 9 / 05\end{array}$ & CPT & $\begin{array}{l}45-50 \\
50-55 \\
55-60 \\
60-65\end{array}$ & $\begin{array}{l}1 \\
1 \\
1 \\
1\end{array}$ & $\begin{array}{l}1.4 \\
\text { ND } \\
0.8 \mathrm{~J} \\
\text { ND }\end{array}$ & $\begin{array}{l}0.4 \mathrm{~J} \\
\mathrm{ND} \\
\mathrm{ND} \\
\mathrm{ND}\end{array}$ & $\begin{array}{l}\text { ND } \\
\text { ND } \\
\text { ND } \\
\text { ND }\end{array}$ \\
\hline SB55 & $6 / 3 / 05$ & СРТ & $45-90$ & 6 & ND & ND & ND \\
\hline SB56 & $\begin{array}{r}5 / 25 / 05- \\
5 / 26 / 05\end{array}$ & СРТ & $48-117$ & 7 & ND & ND & ND \\
\hline SB58 & $\begin{array}{r}5 / 22 / 05- \\
5 / 23 / 05\end{array}$ & СРТ & $\begin{array}{l}48-53 \\
53-58 \\
58-63 \\
63-68\end{array}$ & $\begin{array}{l}1 \\
1 \\
1 \\
1\end{array}$ & $\begin{array}{l}3.0 \\
1.4 \\
1.3 \\
0.7 \mathrm{~J}\end{array}$ & $\begin{array}{l}0.6 \mathrm{~J} \\
0.6 \mathrm{~J} \\
0.2 \mathrm{~J} \\
\mathrm{ND}\end{array}$ & $\begin{array}{l}\text { ND } \\
\text { ND } \\
\text { ND } \\
\text { ND }\end{array}$ \\
\hline SB59 & $\begin{array}{r}\text { 6/6/05- } \\
6 / 7 / 05\end{array}$ & СРТ & $\begin{array}{l}45-50 \\
52-57 \\
59-64 \\
66-71 \\
73-78\end{array}$ & $\begin{array}{l}1 \\
1 \\
1 \\
1 \\
1\end{array}$ & $\begin{array}{r}1,506 \\
487 \\
173 \\
82 \\
27\end{array}$ & $\begin{array}{r}23 \\
18 \\
3.8 \\
2.6 \\
2.4\end{array}$ & $\begin{array}{l}\text { ND } \\
\text { ND } \\
0.6 \mathrm{~J} \\
\text { ND } \\
\text { ND }\end{array}$ \\
\hline
\end{tabular}


TABLE A.5 (Cont.)

\begin{tabular}{|c|c|c|c|c|c|c|c|}
\hline \multirow[b]{2}{*}{ Location } & \multirow[b]{2}{*}{$\begin{array}{l}\text { Sample } \\
\text { Date }\end{array}$} & \multirow[b]{2}{*}{$\begin{array}{l}\text { Sample } \\
\text { Type }^{b}\end{array}$} & \multirow[b]{2}{*}{$\begin{array}{l}\text { Depth } \\
\text { (ft BGL) }\end{array}$} & \multirow[b]{2}{*}{$\begin{array}{c}\text { Number of } \\
\text { Samples }\end{array}$} & \multicolumn{3}{|c|}{ Concentration $(\mu \mathrm{g} / \mathrm{L})$} \\
\hline & & & & & $\begin{array}{c}\text { Carbon } \\
\text { Tetra- } \\
\text { chloride }\end{array}$ & $\begin{array}{l}\text { Chloro- } \\
\text { form }\end{array}$ & $\begin{array}{l}\text { 1,2-Dichloro- } \\
\text { ethane }\end{array}$ \\
\hline SB61 & $\begin{array}{r}\text { 6/4/05- } \\
6 / 5 / 05\end{array}$ & СРТ & $\begin{array}{c}60-65 \\
72-77 \\
81-86 \\
91-96 \\
102-107\end{array}$ & $\begin{array}{l}1 \\
1 \\
1 \\
1 \\
1\end{array}$ & $\begin{array}{l}26 \\
1.4 \\
\text { ND } \\
3.7 \\
\text { ND }\end{array}$ & $\begin{array}{c}16 \\
1.3 \\
\text { ND } \\
2.0 \\
\text { ND }\end{array}$ & $\begin{array}{l}\text { ND } \\
\text { ND } \\
\text { ND } \\
\text { ND } \\
\text { ND }\end{array}$ \\
\hline SB62 & $\begin{array}{r}5 / 24 / 05- \\
5 / 25 / 05\end{array}$ & СРТ & $\begin{array}{l}45-50 \\
50-55 \\
55-60 \\
60-65\end{array}$ & $\begin{array}{l}1 \\
1 \\
1 \\
1\end{array}$ & $\begin{array}{l}31 \\
10 \\
1.5 \\
0.5 \mathrm{~J}\end{array}$ & $\begin{array}{l}5.7 \\
1.0 \\
0.4 \mathrm{~J} \\
0.4 \mathrm{~J}\end{array}$ & $\begin{array}{l}\text { ND } \\
\text { ND } \\
\text { ND } \\
\text { ND }\end{array}$ \\
\hline SB63 & $\begin{array}{r}5 / 18 / 05- \\
5 / 19 / 05\end{array}$ & СРТ & $\begin{array}{l}42.9-47.9 \\
48.2-53.2 \\
52.9-57.9 \\
53.2-58.2\end{array}$ & $\begin{array}{l}1 \\
1 \\
1 \\
1\end{array}$ & $\begin{array}{l}1.1 \\
0.5 \mathrm{~J} \\
0.2 \mathrm{~J} \\
0.5 \mathrm{~J}\end{array}$ & $\begin{array}{l}1.1 \\
\text { ND } \\
\text { ND } \\
\text { ND }\end{array}$ & $\begin{array}{l}\text { ND } \\
\text { ND } \\
\text { ND } \\
\text { ND }\end{array}$ \\
\hline SB64 & $\begin{array}{r}6 / 7 / 05- \\
6 / 9 / 05\end{array}$ & CPT & $\begin{array}{l}42.7-47.7 \\
47.7-52.7 \\
52.7-57.7 \\
57.7-62.7 \\
62.7-67.7\end{array}$ & $\begin{array}{l}1 \\
1 \\
1 \\
1 \\
1\end{array}$ & $\begin{array}{l}1,399 \mathrm{Ce}^{\mathrm{e}} \\
6,413 \\
4,034 \\
1,026 \\
2,686\end{array}$ & $\begin{array}{l}49 \\
49 \\
31 \\
31 \\
66\end{array}$ & $\begin{array}{l}\text { ND } \\
0.9 \mathrm{~J} \\
0.7 \mathrm{~J} \\
1.1 \\
0.9 \mathrm{~J}\end{array}$ \\
\hline SB65 & $\begin{array}{r}6 / 5 / 05- \\
6 / 6 / 05\end{array}$ & СРТ & $\begin{array}{l}50-55 \\
56-61 \\
62-67 \\
68-73\end{array}$ & $\begin{array}{l}1 \\
1 \\
1 \\
1\end{array}$ & $\begin{array}{l}9.4 \\
8.1 \\
5.4 \\
\text { ND }\end{array}$ & $\begin{array}{l}0.6 \mathrm{~J} \\
0.4 \mathrm{~J} \\
0.3 \mathrm{~J} \\
\mathrm{ND}\end{array}$ & $\begin{array}{l}\text { ND } \\
\text { ND } \\
\text { ND } \\
\text { ND }\end{array}$ \\
\hline SB66 & $\begin{array}{r}6 / 7 / 05- \\
6 / 9 / 05\end{array}$ & СРТ & $\begin{array}{c}48-83 \\
88-93 \\
98-111\end{array}$ & $\begin{array}{l}3 \\
1 \\
2\end{array}$ & $\begin{array}{l}\text { ND } \\
0.5 \mathrm{~J} \\
\mathrm{ND}\end{array}$ & $\begin{array}{l}\text { ND } \\
\text { ND } \\
\text { ND }\end{array}$ & $\begin{array}{l}\text { ND } \\
\text { ND } \\
\text { ND }\end{array}$ \\
\hline SB70 & $7 / 11 / 05$ & СРТ & $\begin{array}{l}40-50 \\
55-60 \\
60-65\end{array}$ & $\begin{array}{l}2 \\
1 \\
1\end{array}$ & $\begin{array}{l}\text { ND } \\
0.2 \mathrm{~J} \\
0.5 \mathrm{~J}\end{array}$ & $\begin{array}{l}\text { ND } \\
\text { ND } \\
\text { ND }\end{array}$ & $\begin{array}{l}\text { ND } \\
\text { ND } \\
\text { ND }\end{array}$ \\
\hline SB73 & $\begin{array}{r}6 / 11 / 05- \\
6 / 12 / 05\end{array}$ & СРТ & $\begin{array}{l}43-48 \\
48-53 \\
53-58 \\
63-68\end{array}$ & $\begin{array}{l}1 \\
1 \\
1 \\
1\end{array}$ & $\begin{array}{l}11 \\
9.0 \\
16 \\
\text { ND }\end{array}$ & $\begin{array}{l}2.6 \\
1.0 \\
2.3 \\
\text { ND }\end{array}$ & $\begin{array}{l}\text { ND } \\
\text { ND } \\
\text { ND } \\
\text { ND }\end{array}$ \\
\hline SB75 & $\begin{array}{r}7 / 12 / 05- \\
7 / 13 / 05\end{array}$ & СРТ & $46.5-56.5$ & 2 & ND & ND & ND \\
\hline SB78 & $7 / 13 / 05$ & СРТ & $\begin{array}{l}47.5-52.5 \\
52.5-57.5 \\
57.5-62.5 \\
62.5-67.5\end{array}$ & $\begin{array}{l}1 \\
1 \\
1 \\
1\end{array}$ & $\begin{array}{l}0.6 \mathrm{~J} \\
1.4 \\
0.9 \mathrm{~J} \\
0.2 \mathrm{~J}\end{array}$ & $\begin{array}{l}0.3 \mathrm{~J} \\
0.7 \mathrm{~J} \\
0.6 \mathrm{~J} \\
\mathrm{ND}\end{array}$ & $\begin{array}{l}\text { ND } \\
\text { ND } \\
\text { ND } \\
\text { ND }\end{array}$ \\
\hline
\end{tabular}




\section{TABLE A.5 (Cont.)}

\section{Footnotes:}

a Methylene chloride was not detected in any of these samples at a method detection limit of $0.1 \mu \mathrm{g} / \mathrm{L}$.

b Sample types: CPT, cone penetrometer; MW, monitoring well.

c Qualifier J indicates an estimated concentration below the quantitation limit of $1.0 \mu \mathrm{g} / \mathrm{L}$.

d ND, contaminant not detected at detection limit of $0.1 \mu \mathrm{g} / \mathrm{L}$.

e Qualifier C indicates an estimated result outside the calibration range for the analysis. 
TABLE A.6 Summary of results of organic analyses on groundwater samples collected at or near the

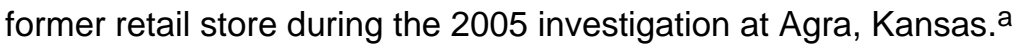

\begin{tabular}{|c|c|c|c|c|c|c|c|}
\hline \multirow[b]{2}{*}{ Location } & \multirow[b]{2}{*}{$\begin{array}{l}\text { Sample } \\
\text { Date }\end{array}$} & \multirow[b]{2}{*}{$\begin{array}{l}\text { Sample } \\
\text { Type }^{b}\end{array}$} & \multirow[b]{2}{*}{$\begin{array}{l}\text { Depth } \\
\text { (ft BGL) }\end{array}$} & \multirow[b]{2}{*}{$\begin{array}{l}\text { Number of } \\
\text { Samples }\end{array}$} & \multicolumn{3}{|c|}{ Concentration $(\mu \mathrm{g} / \mathrm{L})$} \\
\hline & & & & & $\begin{array}{l}\text { Carbon } \\
\text { Tetra- } \\
\text { chloride }\end{array}$ & $\begin{array}{l}\text { Chloro- } \\
\text { form }\end{array}$ & $\begin{array}{l}\text { 1,2-Dichloro- } \\
\text { ethane }\end{array}$ \\
\hline KMW01 & $5 / 19 / 05$ & MW & $43-53$ & 1 & 54.4 & 2.7 & $N D^{c}$ \\
\hline MW-1 & $5 / 19 / 05$ & MW & $41-51$ & 1 & $0.5 \mathrm{~J}^{\mathrm{d}}$ & ND & ND \\
\hline$M W-2$ & $5 / 24 / 05$ & MW & $40-60$ & 1 & 59 & 2.4 & ND \\
\hline SB67 & $\begin{array}{c}7 / 12 / 05- \\
7 / 13 / 05\end{array}$ & СРТ & $\begin{array}{l}46.5-51.5 \\
51.5-56.5 \\
56.5-61.5\end{array}$ & $\begin{array}{l}1 \\
1 \\
1\end{array}$ & $\begin{array}{l}57 \\
35 \\
22\end{array}$ & $\begin{array}{l}3.0 \\
2.3 \\
3.8\end{array}$ & $\begin{array}{l}\text { ND } \\
\text { ND } \\
\text { ND }\end{array}$ \\
\hline
\end{tabular}

a Methylene chloride was not detected in any of these samples at a method detection limit of $0.1 \mu \mathrm{g} / \mathrm{L}$.

b Sample types: CPT, cone penetrometer; MW, monitoring well.

${ }^{c} \mathrm{ND}$, contaminant not detected at detection limit of $0.1 \mu \mathrm{g} / \mathrm{L}$.

${ }^{d}$ Qualifier J indicates an estimated concentration below the quantitation limit of $1.0 \mu \mathrm{g} / \mathrm{L}$. 
TABLE A.7 Summary of results of organic analyses on groundwater samples collected at downgradient CPT locations and permanent monitoring points outside the target investigation areas during the 2005 investigation at Agra, Kansas. ${ }^{a}$

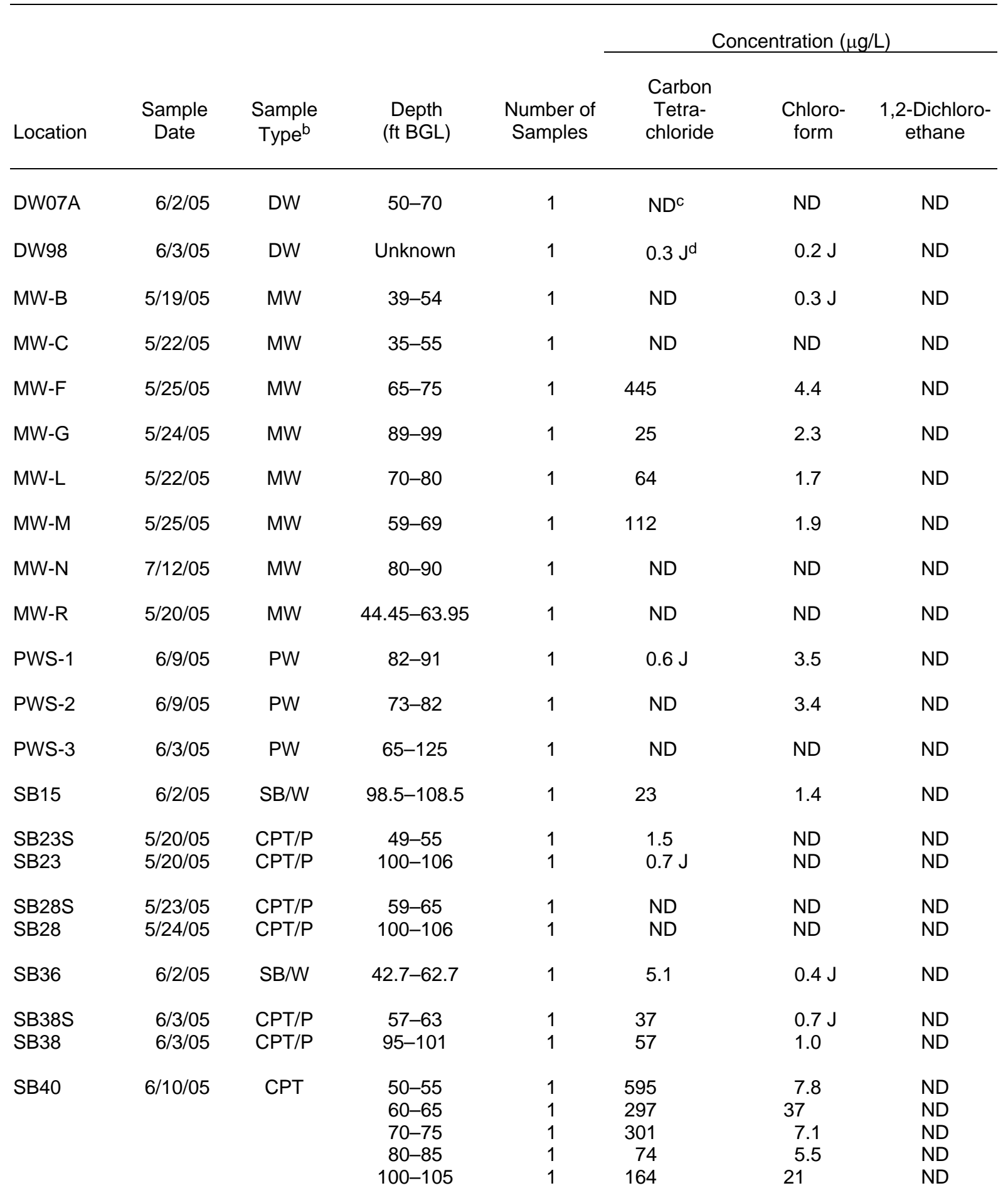


TABLE A.7 (Cont.)

\begin{tabular}{|c|c|c|c|c|c|c|c|}
\hline \multirow[b]{2}{*}{ Location } & \multirow[b]{2}{*}{$\begin{array}{l}\text { Sample } \\
\text { Date }\end{array}$} & \multirow[b]{2}{*}{$\begin{array}{l}\text { Sample } \\
\text { Type }^{b}\end{array}$} & \multirow[b]{2}{*}{$\begin{array}{c}\text { Depth } \\
\text { (ft BGL) }\end{array}$} & \multirow[b]{2}{*}{$\begin{array}{c}\text { Number of } \\
\text { Samples }\end{array}$} & \multicolumn{3}{|c|}{ Concentration $(\mu \mathrm{g} / \mathrm{L})$} \\
\hline & & & & & $\begin{array}{l}\text { Carbon } \\
\text { Tetra- } \\
\text { chloride }\end{array}$ & $\begin{array}{c}\text { Chloro- } \\
\text { form }\end{array}$ & $\begin{array}{l}\text { 1,2-Dichloro- } \\
\text { ethane }\end{array}$ \\
\hline SB41 & $\begin{array}{r}\text { 6/8/05- } \\
6 / 9 / 05\end{array}$ & СРТ & $\begin{array}{l}48-53 \\
58-63 \\
63-68 \\
68-73 \\
73-78\end{array}$ & $\begin{array}{l}1 \\
1 \\
1 \\
1 \\
1\end{array}$ & $\begin{array}{r}50 \\
43 \\
78 \\
94 \\
105\end{array}$ & $\begin{array}{l}1.4 \\
5.4 \\
2.3 \\
2.2 \\
1.6\end{array}$ & $\begin{array}{l}\text { ND } \\
\text { ND } \\
\text { ND } \\
\text { ND } \\
\text { ND }\end{array}$ \\
\hline SB42 & $\begin{array}{r}7 / 7 / 05- \\
7 / 9 / 05\end{array}$ & СРТ & $\begin{array}{c}50-55 \\
65-70 \\
80-85 \\
95-130 \\
140-145\end{array}$ & $\begin{array}{l}1 \\
1 \\
1 \\
3 \\
1\end{array}$ & $\begin{array}{l}43 \\
60 \\
0.8 \mathrm{~J} \\
\mathrm{ND} \\
0.2 \mathrm{~J}\end{array}$ & $\begin{array}{l}1.3 \\
1.3 \\
\text { ND } \\
\text { ND } \\
\text { ND }\end{array}$ & $\begin{array}{l}\text { ND } \\
\text { ND } \\
\text { ND } \\
\text { ND } \\
\text { ND }\end{array}$ \\
\hline SB72 & $7 / 12 / 05$ & СРТ/P & $59-69$ & 1 & $0.7 \mathrm{~J}$ & $0.2 \mathrm{~J}$ & ND \\
\hline SB79 & 7/14/05 & СРT & $\begin{array}{l}50-55 \\
55-60 \\
60-65\end{array}$ & $\begin{array}{l}1 \\
1 \\
1\end{array}$ & $\begin{array}{c}13 \\
10 \\
3.0\end{array}$ & $\begin{array}{l}1.3 \\
0.6 \mathrm{~J} \\
0.7 \mathrm{~J}\end{array}$ & $\begin{array}{l}\text { ND } \\
\text { ND } \\
\text { ND }\end{array}$ \\
\hline SB80 & $7 / 14 / 05$ & СРТ & $\begin{array}{c}50-55 \\
55-60 \\
60-64.75\end{array}$ & $\begin{array}{l}1 \\
1 \\
1\end{array}$ & $\begin{array}{l}13 \\
9.7 \\
4.9\end{array}$ & $\begin{array}{l}0.6 \mathrm{~J} \\
1.1 \\
3.8\end{array}$ & $\begin{array}{l}\text { ND } \\
\text { ND } \\
\text { ND }\end{array}$ \\
\hline
\end{tabular}

a Methylene chloride was not detected in any of these samples at a method detection limit of $0.1 \mu \mathrm{g} / \mathrm{L}$.

b Sample types: CPT, cone penetrometer; CPT/P, piezometer; DW, domestic well; MW, monitoring well; PW, public water supply well; SB/W, drilled monitoring well.

c ND, contaminant not detected at a detection limit of $0.1 \mu \mathrm{g} / \mathrm{L}$.

${ }^{d}$ Qualifier J indicates an estimated concentration below the quantitation limit of $1.0 \mu \mathrm{g} / \mathrm{L}$. 
Argonne

Environmental Science Division

Argonne National Laboratory

9700 South Cass Avenue, Bldg. 203

Argonne, IL 60439-4843

www.anl.gov

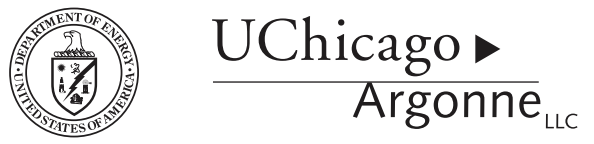

A U.S. Department of Energy laboratory

managed by UChicago Argonne, LLC 